\title{
Using Graph Software in Teaching the Subject of Functions: The Case of Azerbaijan
}

\author{
Malahat Abdullayeva \\ Azerbaijan State Pedagogical University, Baku/Azerbaijan (ORCID: 0000-0002-2228-1224)
}

Article History: Received: 10 January 2020; Accepted: 30 September 2020; Published online: 13 January 2021

\begin{abstract}
In this study, the features of Graph 4.4 software used in mathematics lessons are introduced and the development of students' ability to create and interpret function graphs as a result of using this software is examined. The study was designed and conducted as an experimental study. The sample consists of 46th grade 8th grade secondary school students (24 students in the experimental group, 22 students in the control group). In the experimental group, the topic of functions was taught using Graph 4.4 software. At the end of the application, 2 questions were asked to both groups that required graphing and interpretation to answer. The written answers of the students were analyzed by scoring in three categories as correct, partially correct and false. Throughout the comparison, it was determined that the averages of the experimental group were higher. The findings revealed that the use of dynamic algebra software in mathematics lessons improved students' graphic skills. Although this result obtained from a small sample cannot be generalized, this study shows that the use of Graph 4.4 software in mathematics lessons can be one of the basic teaching tools.
\end{abstract}

Keywords: Graph software, mathematics, graphics of functions

DOI:10.16949/turkbilmat.673284

Öz: $\mathrm{Bu}$ çalıșmada matematik derslerinde kullanılan Graph 4.4 yazılımının özellikleri tanıtılmakta ve bu yazılımın fonksiyonların grafiklerinin öğretiminde kullanılması sonucunda öğrencilerin fonksiyon grafiklerini oluşturma ve yorumlama becerilerindeki gelişim incelenmektedir. Çalışma deneysel bir çalışma olarak tasarlanarak yürütülmüştür. Örneklemi 46. ( $\mathrm{n}=24$ deney grubu, $\mathrm{n}=22$ kontrol) 8. sınıf ortaokul öğrencileri oluşturmaktadır. Deney grubunda fonksiyonlar konusu Graph 4.4 yazılımı kullanılarak işlendi. Uygulamanın sonunda her iki gruba cevaplamaları için grafik oluşturmayı ve yorumlamayı gerektiren 2 soru soruldu. Öğrencilerin yazılı cevapları doğru, kısmen doğru ve yanlış şeklinde üç kategoride puanlanarak analiz edilmiştir. Yapılan karşılaştırmada deney grubunun ortalamalarının daha yüksek olduğu belirlenmiştir. Bulgular matematik derslerinde dinamik cebir yazılımlarının kullanılmasının öğrencilerin grafik becerilerini geliştirdiğini ortaya çıkarmıştır. Küçük bir örneklemden elde edilen bu sonuç genellenemese bile, bu çalışma matematik derslerinde Graph 4.4 yazılımı kullanımının temel öğretim araçlarından biri olabileceğini göstermektedir.

Anahtar Kelimeler: Graph yazılımı, matematik, fonksiyon grafikleri

Türkçe sürüm için tıklayınız

\section{Introduction}

Technology is growing rapidly. This development also changes the practices in the education system. In this respect, mathematics education should be adapted according to the developments in science and technology. The use of ICT in mathematics classrooms helps students to construct and develop their knowledge, skills and habits in the subjects they learn, and to apply them to real-life situations. At the same time, when students do their homework by using on the computer using special software also will encourage them to fulfill more difficult homework in the next.

Today, many studies are carried out on the transition from "memory" school to "thinking" school in general education systems (Peter, 2012). Now, the use of new teaching technologies, computers, smart boards, the internet and other multimedia tools, has become an inevitable requirement to achieve high quality in education. It has become impossible to think especially mathematics teaching without computer applications. Computer technology provides the most effective way to communicate and access information. Now coputer has become an indispensable assistant tool for teaching in mathematics lessons. The use of ICT in mathematics classes creates the opportunity for students to be more active learner and at the same time creates scientific perspectives, habits of working with data, allows the subject learned to remain in mind for a long time while being careful and creates a source of motivation to do it (Tagiyeva, Hesenov, \& Cebrayılzade, 2011). Softwares such as Mathcad11, MATLAB-7, Scientific Work Place 5.0, Graph 4.4 are used in mathematics lessons.

Algebra and functions are one of the basic learning areas of the secondary school mathematics curriculum (Azerbaijan Ministry of National Education, 2006). This learning area acts as a bridge for learning other areas. Through algebra, students solve problems from a natural language in algebra, symbolically and vice versa. Functions section, one of the main areas of mathematics study, serves students' mastery of equations, variables and quantitative relationships. The scope of this section in the learning area is expanding in the upper classes and

Corresponding Author: Malahat Abdullayeva (D) email: azeriteacher@yahoo.com

Citation Information: Abdullayeva, M. (2021). Using Graph software in teaching the subject of functions: The case of Azerbaijan. Turkish Journal of Computer and Mathematics Education, 12(1), 71-95. http://doi.org/10.16949/turkbilmat.673284 
is of extraordinary importance. While teaching the topic of algebra and functions, a large number of problems are analyzed, modeled, solved and presented. Research shows that many high school students have trouble creating graphs of functions and presenting results. The use of mathematical tools and technologies in the new curriculum is necessary to overcome difficulties and improve mathematical skills (Azerbaijan Ministry of National Education, 2013).

In this study, after giving information about the properties and usage of Graph 4.4 application software (Johansen, 2012), the use of software in teaching the subject of functions in a mathematics classroom, the student's ability to graph the function and interpret it is examined. Therefore, the research problem is determined as follows:

Do what extent the use of graphical software in teaching quadratic equations and equations with rational expressions and their graphs affect students' ability to graph the function and interpret it?

\subsection{Technical features of the Graph 4.4 software}

Graph 4.4 software is one of the perfect software for building students' graphing skills. The Graph 4.4 application is an open source software used to create graphs in a two-dimensional Cartesian coordinate system. After installing the graphics of the functions, they can be added easily. Some mathematical calculations can also be made on functions through the software in question. The footprint of the software allows it to be kept on any disk drive and easily moved from one location to another.

When the software package is downloaded to the computer, the main page window of the software will open on the screen as below (Figure 1):

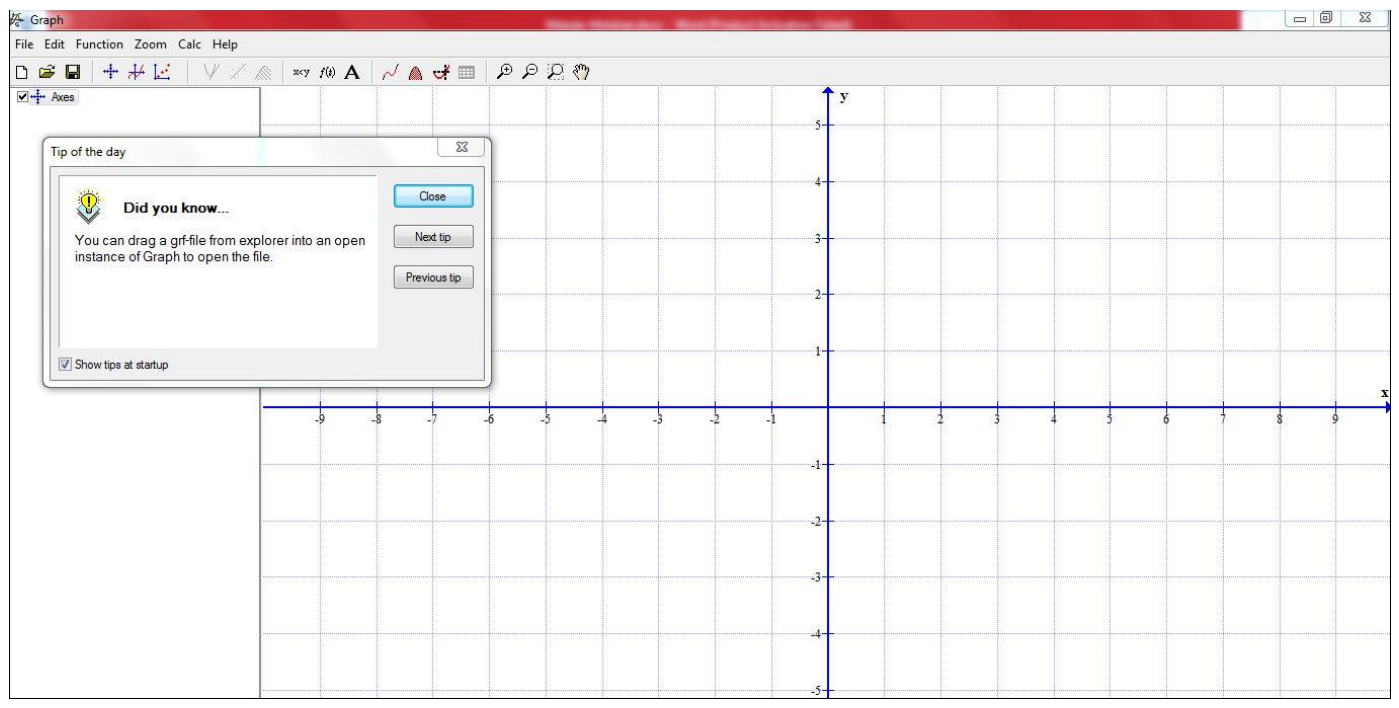

Figure 1. Graph Sofware Page

Menu items consist of sub menus and tools panel. The items of the title line of the window are similar to other software windows, but some menu items and submenu items are different from other software. When opening the window, there is a consultative dialog in its middle part. After answering the relevant question in this window, a new window will open. The window in question has three management buttons. The first of these allows you to close the window, while others allow you to return to the next and previous question.

The series first four items of the "File" item of the menu have the same character. The fifth "Save as image" section moves the same image software page to memory with a new name. When this command is requested, the dialog window will open in response to the command. The file name will be written in the "File name" section of the window in question. The sixth item of this menu called Import is for downloading other images from the software itself. . In the "Function type" section of the dialog box, one of the three types of functions is preferred as standard, parameterized or polar function. In the "Function equation" field, it is necessary to write the equation of the corresponding function. In the opened dialog box, the interval and step where the graph of the function will be created, the graph display type, color, size, sign type, color, size and other parameters must be selected. Then, pressing the OK command button sets the chart automatically. This dialog box also has an auxiliary button and option to cancel the command. By the way, it is possible to create graphs for several functions in a coordinate system. This is an important factor to compare while learning the graphs of functions (Figure 2). The second sub-menu is used to touch, cut or draw vertically on the given point by passing the name "Insert tangent / normal". 
This software can be used successfully not only in creating the graph, but also in solving the equation problem with graphical method. When using the software, the unknowns specific to the equation problem, the complexity of the degree size of the variable, etc. it does not create any difficulties during the solution. It is known that the time spent solving such equations with the traditional method is much more than the time spent using Graph software. If we add here the accuracy of the installation, we conclude that this software has a unique advantage.

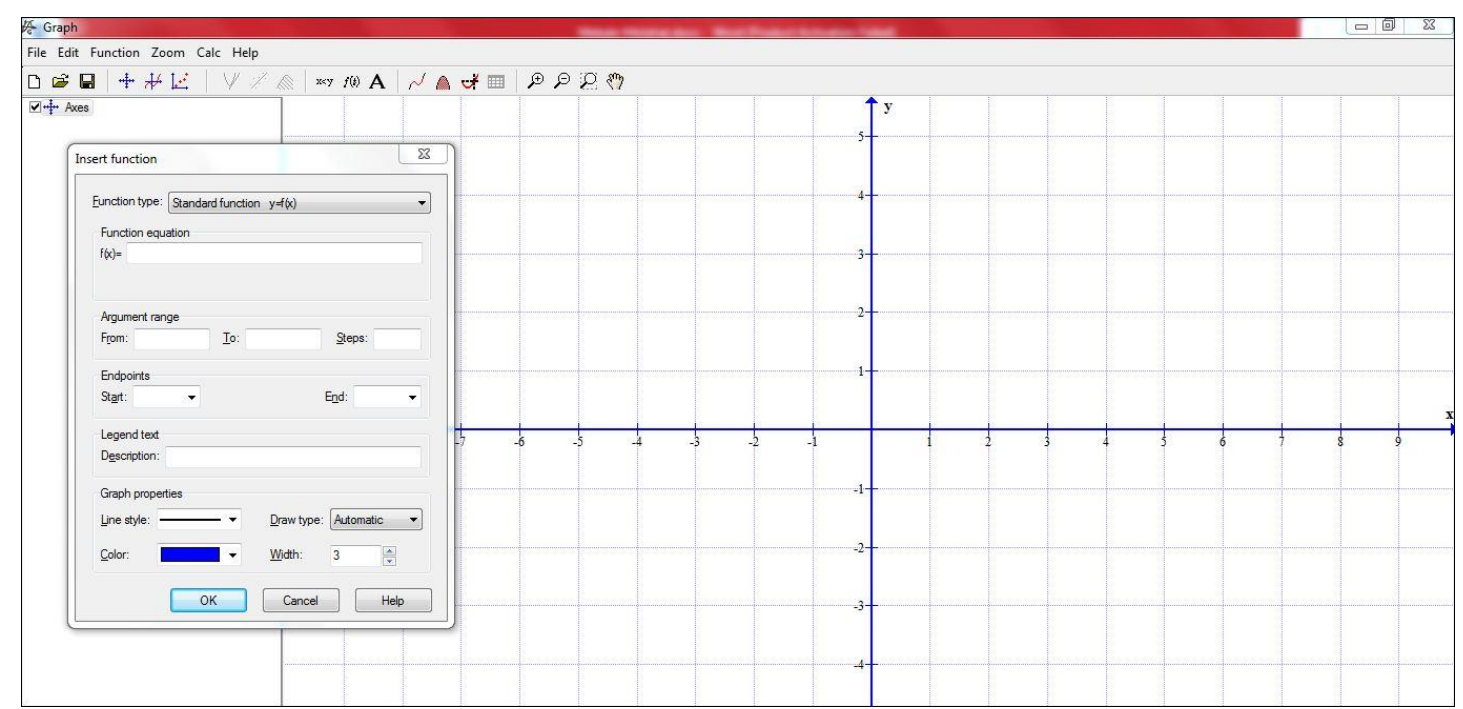

Figure 2. "Insert function" window of "Function" menu in Graph software.

The next is "Add Shading". This unite also provides rich possibilities. That is, the shading of the gaps is of great importance in solving inequalities. The traditional method is a very time consuming and messy task. In addition, when the number of unknowns and shaded areas are high, the clutter becomes more apparent. But using this software not only eliminates shortcomings, but also helps create new opportunities. Using Graph 4.4 application allows shading in six directions in the Cartezian coordinate system:

1. Shading of the area between the function graph and the OX axis;

2. Shading the lower part of the function chart;

3. Shading the upper part of the graph of the function;

4. Shading the area between the graph of the function and the OY axis;

5. Shading the inside of the graph of the function;

6. Shading the inter graphical distance of functions (Abdullayeva, 2012).

"Insert $\mathrm{f}^{\prime}(\mathrm{x})$ " to create the graph of the derivative of the function, "Insert point series" to indicate points on the graphs (Insert point series ")," Insert relation "to make new function graphs," Add text "to name points, write formulas. You can use the sub menus of the "Function" menu named "Special Functions / Constants" (Special functions / constants) to enter special functions. In the Caretesian coordinate system, problems may arise when using "Zoom" to change the dimensions of the graphics and "Calc" for calculation. In this case, using the "Help" menus to get help creates a better environment for the user.

Example-1: $\left\{\begin{array}{l}2 x+y=1 \\ 2 x-y=3\end{array}\right.$ graphically solve the system of equations. Record the intersection points of the graph of each equation in the expression with the OX and OY axes (İsmayalova, 2014)."

Solution: Let's solve the equation system with Graph 4.4. First, both equations of the system are rearranged according to $\mathrm{y}$ as $\left\{\begin{array}{l}y=-2 x+1 \\ y=2 x-3\end{array}\right.$

Let's write $-2 x+1$ and $2 x-3$ expressions in the "Insert equation" field in the "Add function" submenu of the "Function" menu in the software that is, in the form of $-2 * x+1$ and $2 * x-3$. For each equation, the range, step, type of graph display, color, thickness, marker with appropriate parameters, etc. is selected and graphics will be automatically installed in the system. Using other options, it is possible to specify each equation on the appropriate graph. Find the coordinates of the intersection point with the OX and OY axes of each graph and fill it easily. If we put the arrow of the mouse over the intersection of the graphs, we can see that the coordinates of that point are 1 and -1 . Thus, the coordinates of the intersection point of straight lines are $A(1 ;-1)$. By moving the mouse again to the intersection point with the coordinate arrows of each graph, you can see the coordinates 
of that point in the lower right corner of the screen. The graph of the $2 x+y=1$ equation intersects the $\mathrm{OX}$ axis at the point $\mathrm{B}(0,5 ; 0)$ and the $\mathrm{OY}$ axis at the point $\mathrm{C}(0 ; 1)$. The graph of the $2 \mathrm{x}-\mathrm{y}=3$ equation cuts the $\mathrm{X}$ axis at the point $\mathrm{D}(1,5 ; 0)$ and the $\mathrm{Y}$ axis at the point $\mathrm{K}(0 ;-3)$ (Figure 3$)$ :

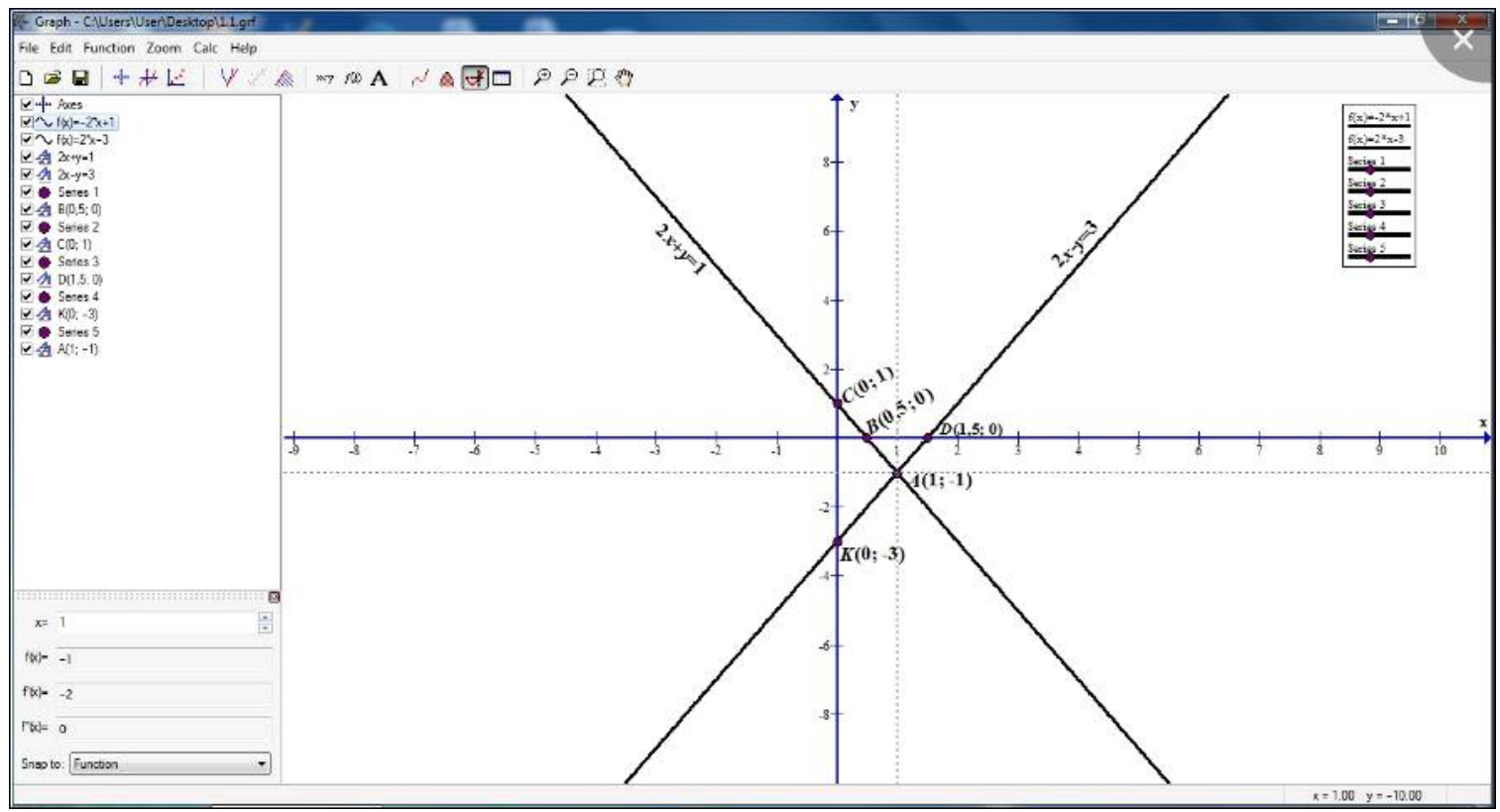

Figure 3. Solution of the equation system by graphical method

Example 2. Solve this equation system graphically $\left\{\begin{array}{l}3,5|x|-y=2 \\ y+x^{2}-6=0\end{array}\right.$ (Merdanov, 2010).

Solution: Let's express $\mathrm{y}$ as $\mathrm{x}$ in both equations as $\left\{\begin{array}{l}y=3,5|x|-2 \\ y=6-x^{2}\end{array}\right.$

In the "Insert function" sub-menu item of the Graph 4.4 software's "Function menu," add $3.5|x|$ to the "Add equation" field. - Write the equation 2 in programming language. Then, let's choose the interval, step, display type of the chart, color, thickness, the marker with the appropriate parameters and automatically create our chart in the system according to the equation. Similarly, after setting the $6-x 2$ equation in programming language, it is possible to create the graph by selecting the parameters (Figure 4). The charts intersect at points A (1.5716; $3.5006)$ and $\mathrm{B}(-1.5716 ; 3.5006)$. Thus, $(1.57,3.51)$ and $(-1.57 ; 3.51)$ pairs will be the approximate solution to the equation:

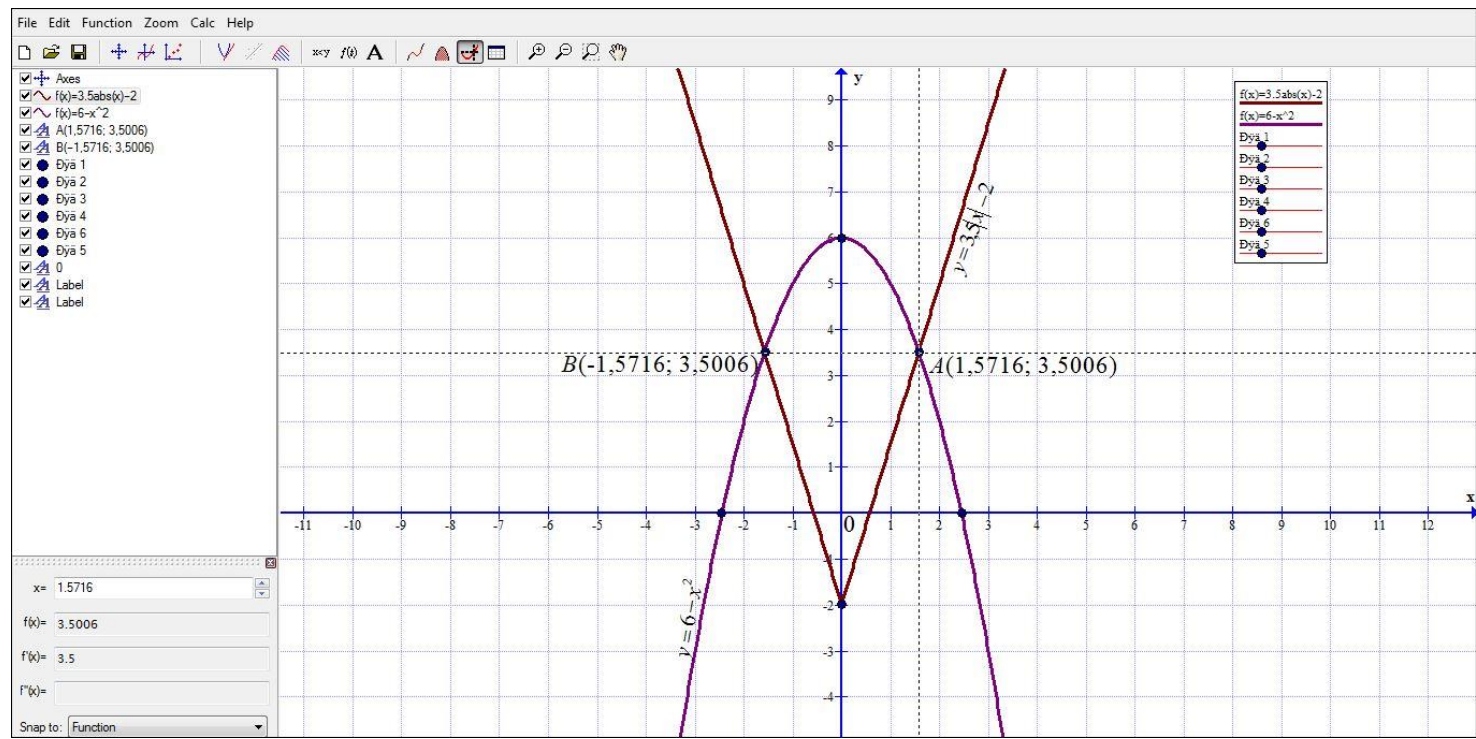

Figure 4. The graphical solution of the equation system

Example 3: Calculate the area of the shape bounded by lines $y=e^{x}, y=0, x=0, x=1$ (Merdanov, 2009). 
Solution: First, let's write the equation $y=e^{x}$ and $y=0$ in the "Insert equation" in "Insert function" sub-menu item of the "Function" menu of Graph 4.4 software. Graphics, interval, step, graphic display type, color, thickness, and appropriate parameters are automatically adjusted to the system by selecting the marker (Figure 5). Then, let's enter that the «Function» item is $\mathrm{x}=0$ and $\mathrm{x}=1$ in the "Edit relation" field in the "Insert relation" submenu item. By using the "Insert text label" window in the "Insert label" submenu of the "Function" item, you can define the bent trapeze, write formulas on the graphics or mark any symbol. To calculate the area of the bent trapeze obtained, you can use $[0 ; 1]$ data is entered and the area is calculated automatically. Thus, the requested area is equal to 1.7183 or (e-1):

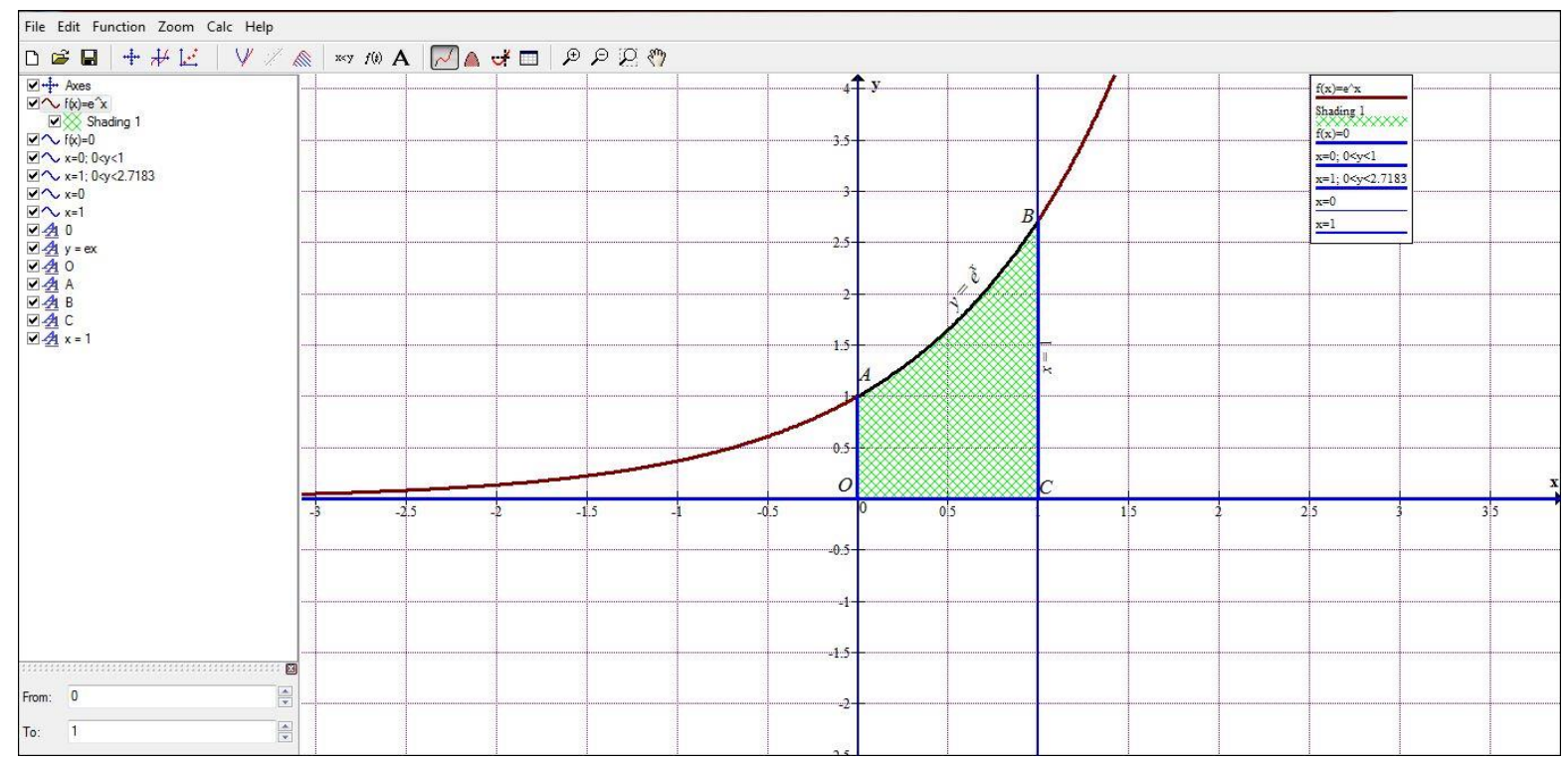

Figure 5. Calculation of the area of the bent trapeze

Example- 4. Calculate the area of the shape bounded by $y=\frac{2}{x}, y=0, x=1, x=4$ (Merdanov, 2009).

Solution: Similarly, let's create our graph after entering the $\mathrm{y}=2 * 1 / \mathrm{x}$ and $\mathrm{y}=0$ functions in the "Insert equation" field in the "Insert function" submenu of the "Function" item of the Graph 4.4 software in programming language and selecting the appropriate settings (Figure 6). In the "Area" sub-menu item of the "Calc" item [1; 4], we can see that the area equals approximately 2.7726 :

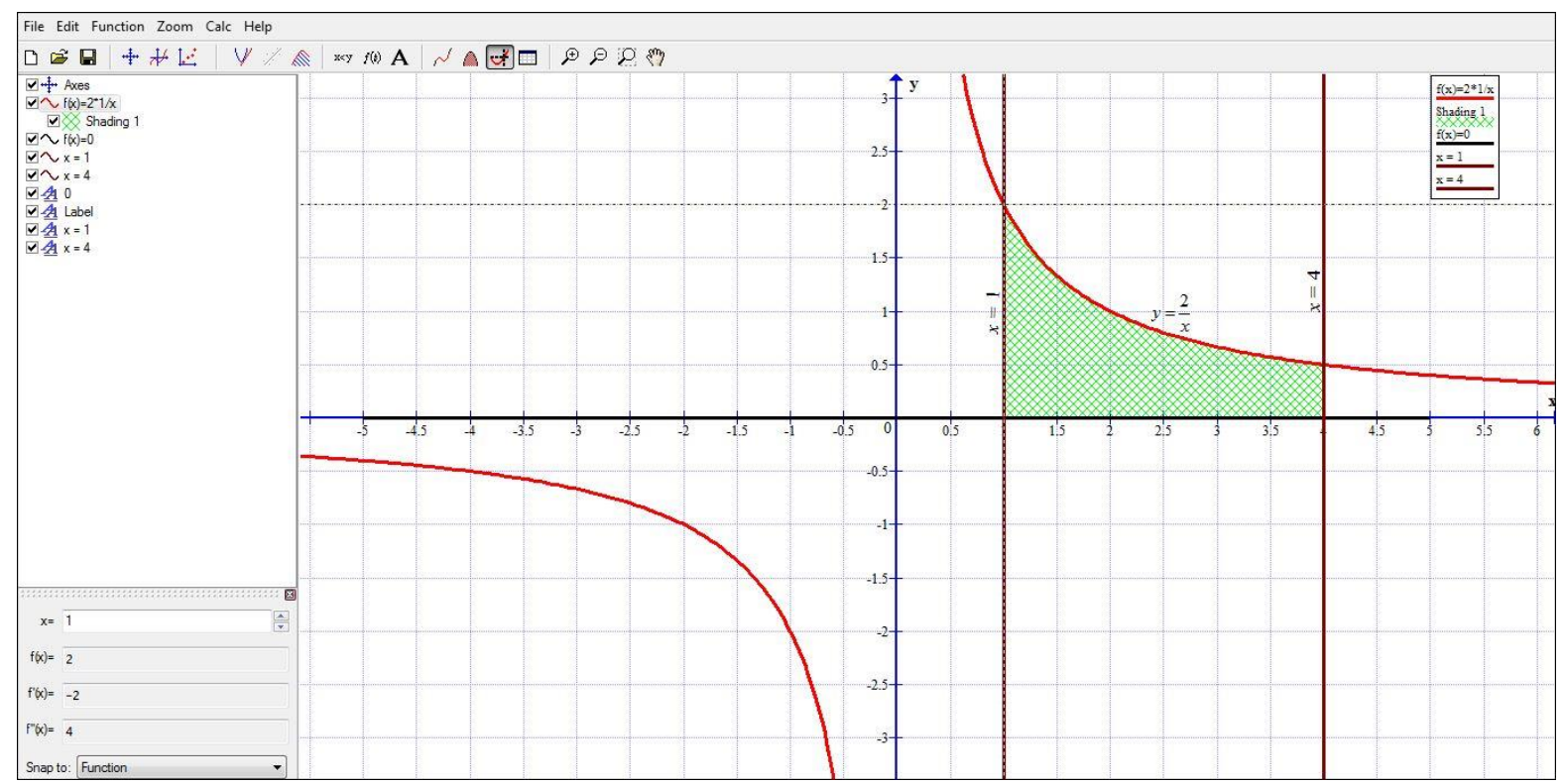

Figure 6. Calculation of the area of the bent trapeze

Example 5. Calculate the area of the shape bounded by $y=3 x-x^{2}, y=0$ (Merdanov, 2009). 
Solution: First, let's find the axes of the intersections of the graphs. Let's solve the equation for this. The solution of the equation will be $x_{1}=0$ and $x_{2}=3$. Then, similarly, let's create our graph after entering the $y=3 x-x^{2}$ and $y=0$ functions in the "Insert equation" field in the "Insert function" submenu of the "Function" menu of the Graph 4.4 software and selecting the appropriate settings (Figure 7). In the "Area" sub-menu item of the "Calc" menu [0;3], we get that the area is approximately equal to 4.5 :

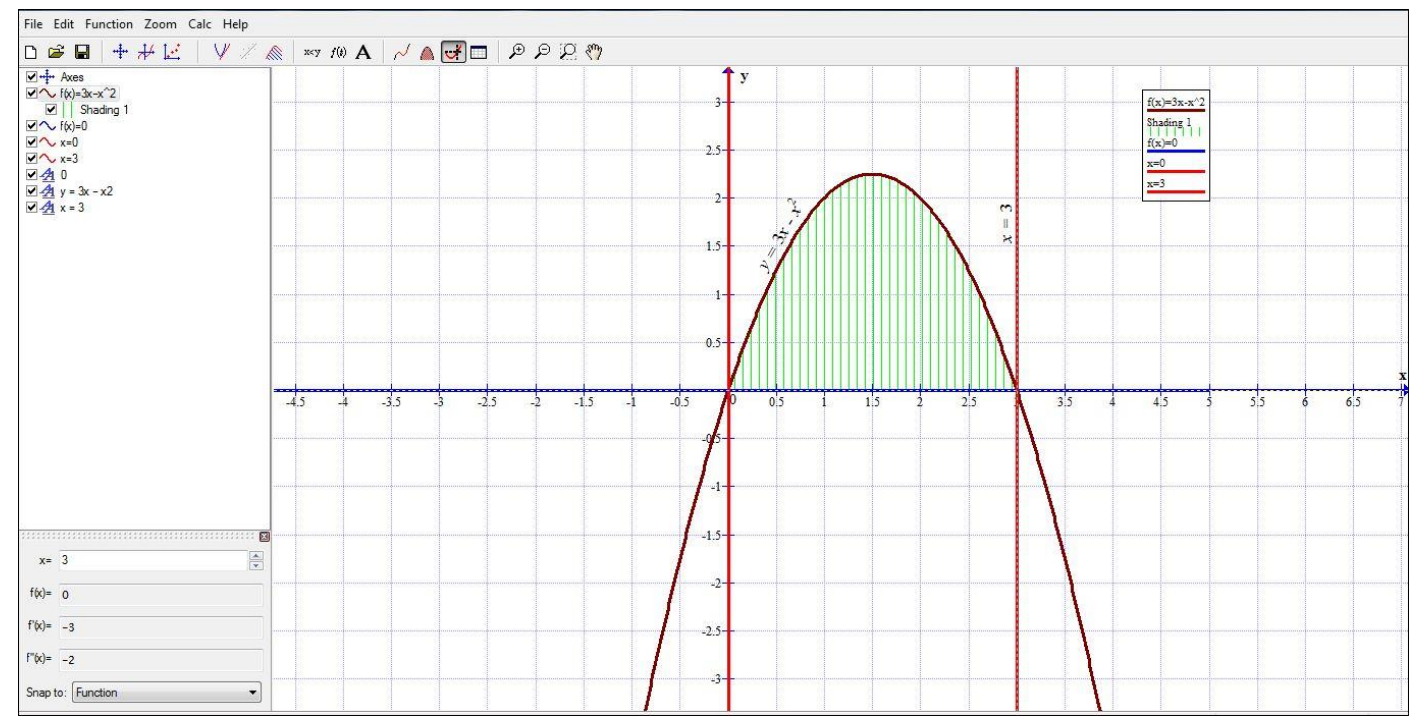

Figure 7. Calculation of the shaded area

\section{Method}

\subsection{Research Design and Participants}

The study was carried out in a secondary school in Baku in the 2017-2018 academic year. Before the study, the teaching practices of mathematics teachers in some secondary schools in Baku was observed, approximately 30 ( $\mathrm{n}<30$ ) mathematics teachers and 180 eighth grade students were interviewed and a questionnaire was applied. The questionnaire asked "How would you like to learn mathematics?" A question was asked. 85\% of the students answered "I want to learn with the help of computer technology".

The study was initiated with the hypothesis that if Graph 4.4 software is used in mathematics teaching in the 8th grade, the quality of teaching will increase, students will be motivated to learn mathematics and as a result, they will develop more graphing and interpretation skills. The validity of the hypothesis was tested in an experimental study and the results were compared.

The research was carried out as an experimental design. Two 8th grades of middle school No 21 in Baku were considered, one of them was defined as random control class $(n=22)$ and the other as experimental class $(\mathrm{n}=24)$. The second order equations and rational equations, which are sub-learning areas of the eighth grade mathematics curriculum, were explained in the experimental group using Graph 4.4 software. In the control group, these subjects were taught in a classroom where the smart board was not used by following the existing math book.

The study was conducted as an experiment design. The sample of the study cosisted of two separate 8th classes of the secondary school 21 in Baku. One of them was randomly selected as the control group $(\mathrm{n}=22)$ and the other as the experimental group $(n=24)$. The second order equations and rational equations, which are sub-learning areas of the eighth grade mathematics curriculum, were tought in the experimental group through using the Graph 4.4 program. In the control group, these topics were studied in a classroom where the smart board was not used after the existing mathematics book.

At the end of the first half of the school year, a test was applied to compare graphic skills in the experimental and control classes. This experiment was done by the class using Graph 4.4 and the control class using paper and pencil. The questions used in the test are defined as follows:

Question 1. Graph the function of $y=\frac{8}{x}$ and find the defined region..

Question 2. $3 x^{2}+5 x-3=0$ equation is given. Show your graphical solution (Qehramanova, Kerimov, \& Hüseynov, 2015). 


\subsection{Data analysis}

The written answers of the students in both control and experimental classes were analyzed by scoring in three categories as complete correct, partially correct and incorrect.

The criteria to be used to evaluate the answers given to the first question in the control group were determined as follows:

The function created with the formula $y=\frac{k}{x}$ is called an inverse proportional function. Here $\mathrm{x}$ is independent variable $(x \neq 0), k$ is a nonzero digit. Since the function presented by the formula $y=\frac{8}{x}$ is an inversely proportional function, the area is the set of all real numbers except zero. The graph of an inversely proportional function is called a hyperbola and consists of two branches. Since $k=8>0, x$ and $y$ will be equally conditional, and hyperbola branches are in the first and third of the coordinate plane. will take place in the I. And III: regions. To create the graph of the function $y=\frac{8}{x}$, first the table of numbers is created (Table 1), then the graph is created (Figure 8):

Table 1. table of values for the function $y=\frac{8}{x}$

\begin{tabular}{|l|l|l|l|l|l|l|l|l|l|}
\hline$X$ & -8 & -4 & -2 & -1 & 0 & 1 & 2 & 4 & 8 \\
\hline$Y$ & -1 & -2 & -4 & -8 & undefined & 8 & 4 & 2 & 1 \\
\hline
\end{tabular}

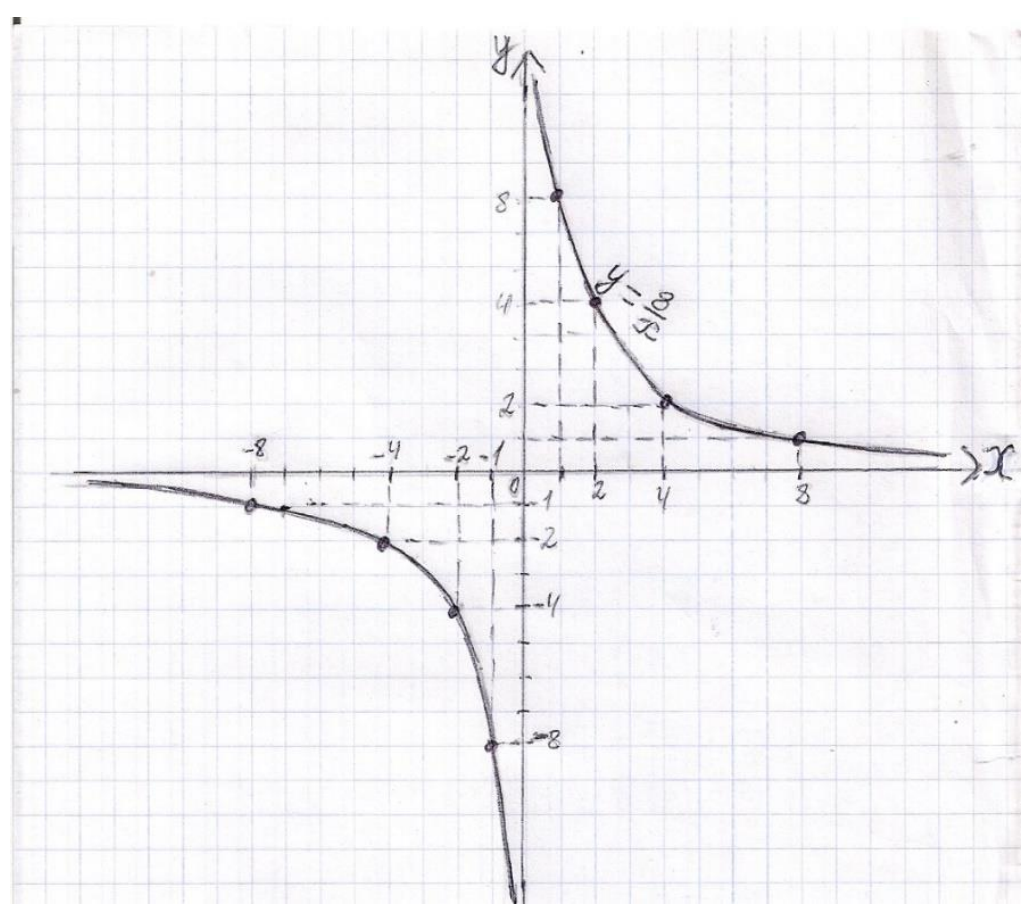

Figure 8. Graph of $y=\frac{8}{x}$

Only the answer of the students who created the graph of the function correctly was evaluated as partially correct answer, and the answers of the students who did not write the designated area of the function and did not set the program correctly were evaluated as wrong answer. Students were evaluated in rubrics that define the levels of their skills in graphically presenting inversely proportional addiction (Gehramanova, Kerimov \& Huseynov, 2019) (see Table 2).

Table 2. Evaluation for control class presentation skills

\begin{tabular}{|c|c|c|}
\hline $\begin{array}{c}\text { Level-I } \\
\text { wrong answer }\end{array}$ & $\begin{array}{l}\text { Level-II } \\
\text { Partially correct answer }\end{array}$ & $\begin{array}{c}\text { Level-III } \\
\text { Correct answer }\end{array}$ \\
\hline $\begin{array}{l}\text { It is difficult to draw inverse } \\
\text { proportional dependencies. }\end{array}$ & $\begin{array}{l}\text { Presenting } \\
\text { proportional dependency with } \\
\text { help. }\end{array}$ & $\begin{array}{l}\text { The inverse proportional dependency } \\
\text { is completely presented graphically. }\end{array}$ \\
\hline
\end{tabular}

In this table, Level I shows wrong answers, Level II shows correct but incomplete answers and Level III shows correct and complete answers.

The criteria to be used for the evaluation of the answers to the second question in the control group were determined as follows: 
The correct and complete answer is: writing the equation $3 x^{2}+5 x-3=0$ in the form of $3 x^{2}=-5 x+3$ and dividing both sides by 3 as $x^{2}=-\frac{5}{3} x+1$. Creating the graph of $y=x^{2}$ and $y=-\frac{5}{3} x+1$ functions on the same coordinate plane (Figure 9). Compiling a table of values for each function (Table 3):

Table 3. Values tables for $y=x^{2}$ and $y=-\frac{5}{3} x+1$

\begin{tabular}{|c|c|c|c|c|c|c|c|}
\hline$x$ & -3 & -2 & -1 & 0 & 1 & 2 & 3 \\
\hline$y=x^{2}$ & 9 & 4 & 1 & 0 & 1 & 4 & 9 \\
\hline
\end{tabular}

\begin{tabular}{|c|c|c|c|}
\hline$x$ & -3 & 0 & 3 \\
\hline$y=-\frac{5}{3} x+1$ & 6 & 1 & -4 \\
\hline
\end{tabular}

The abscissa of the intersection points of the parabola $y=x^{2}$ and the straight line $y=-\frac{5}{3} x+1$ will be the root of the given equation. Since the straight line intersects the parabola, the equation has two different roots: $x_{1} \approx-2,2$ and $x_{2} \approx 0,5$.

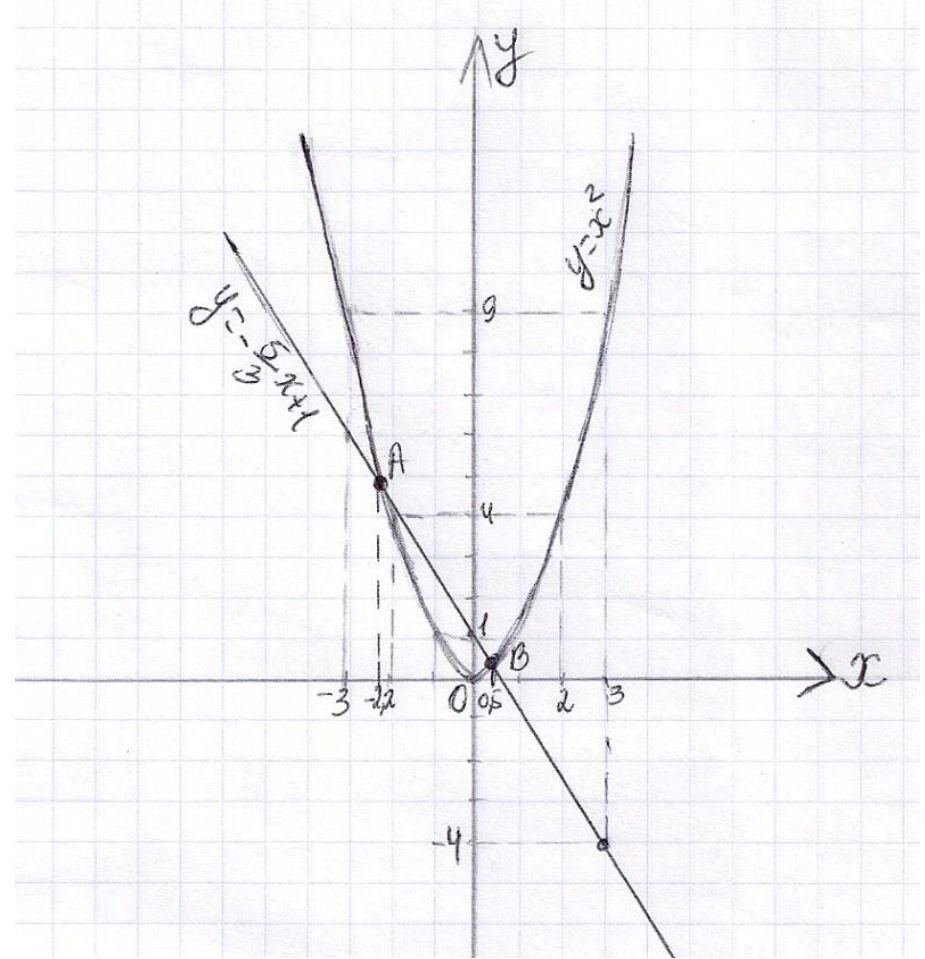

Figure 9. Graph of $3 x^{2}+5 x-3=0$

The evaluation of this question was carried out according to the objective of "It investigates the origins of the quadratic equation by drawing the graphs of the corresponding functions on the same coordinate plane" (Gehramanova, Kerimov \& Huseynov, 2019). (Table 4).

Table 4. The evaluation of ansvers to $3 x^{2}+5 x-3=0$ in control group

\begin{tabular}{|l|l|ll}
\hline \multicolumn{1}{|c|}{$\begin{array}{c}\text { Level I } \\
\text { Wrong answer }\end{array}$} & \multicolumn{1}{|c}{ Level II } & \multicolumn{1}{c}{$\begin{array}{c}\text { Level III } \\
\text { Correct answer }\end{array}$} \\
\hline $\begin{array}{l}\text { To find the roots of a quadratic } \\
\text { equation, it is difficult to construct } \\
\text { graphs of its corresponding } \\
\text { functions on the same coordinate } \\
\text { plane. }\end{array}$ & $\begin{array}{l}\text { To find the roots of a quadratic } \\
\text { equation, it creates the graphs of its } \\
\text { corresponding functions on the } \\
\text { same coordinate plane, but } \\
\text { examines them with the help of } \\
\text { their roots. }\end{array}$ & $\begin{array}{l}\text { Corresponding functions of the } \\
\text { roots of quadratic equation in the } \\
\text { same coordinate plane and } \\
\text { completely examines the roots. }\end{array}$ \\
\hline
\end{tabular}

If a student cannot create a straight line graph with a parabola on the same coordinate plane, his answer is considered incorrect.

$\checkmark \quad$ Student creates a straight line graph with parabola on the same coordinate plane

$\checkmark$ but if he finds the origins of the quadratic equation with the help of the teacher, this answer is considered to be partially correct.

$\checkmark$ If the student draws a straight line with a parabola on the same coordinate plane and freely searches for the roots of the quadratic equation, this answer is considered the correct answer. 
The analysis of the answers given to the first question in the experimental group was as follows:

The area where the function $y=\frac{8}{x}$ is defined are all real numbers other than 0 : The graph of the function $x \neq 0$, $y=\frac{8}{x}$. created in Graph 4.4 software (Figure 10) is as follows:

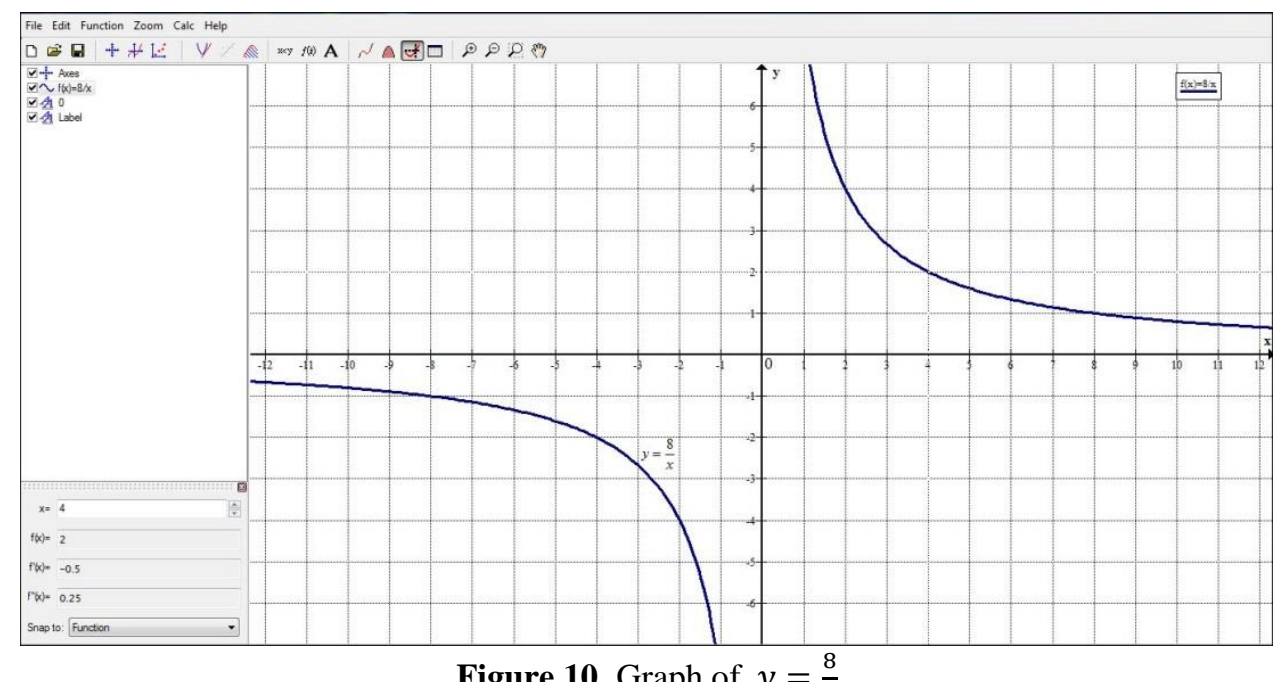

Figure 10. Graph of $y=\frac{8}{x}$

The answers to the first question were evaluated according to the Table 5:

Table 5. Evaluationcriteria for the 1st question in the experiment group

\begin{tabular}{c|l|l}
$\begin{array}{c}\text { Level I } \\
\text { Wrong answer }\end{array}$ & \multicolumn{1}{|c|}{$\begin{array}{c}\text { Level II } \\
\text { Partially correct answer }\end{array}$} & \multicolumn{1}{c}{$\begin{array}{c}\text { Level III } \\
\text { Correct answer }\end{array}$} \\
\hline $\begin{array}{l}\text { icult to present an inverse } \\
\text { onality graph using Graph }\end{array}$ & $\begin{array}{l}\text { Graph } 4.4 \text { presents a graph of } \\
\text { inverse proportionality with the help } \\
\text { of notation.. }\end{array}$ & $\begin{array}{l}\text { Graph 4.4 provides an inverse } \\
\text { proportionality graph. }\end{array}$ \\
\hline
\end{tabular}

The correct and complete answer to the second question in the experimental group is as follows:

Replacing the equation $3 x^{2}+5 x-3=0$ with the equation $3 x^{2}=-5 x+3$ that is the same as it is. Then using the quadratic equation transformed by dividing both sides of the equation by 3 and doing the graphical solution of $y=-\frac{5}{3} x+1$.

Then creating graphs of $y=x^{2}$ and $y=-\frac{5}{3} x+1$ in Graph 4.4 software. Determination of the abscissa of the intersection spurs of the graphs as -2.138 and 0.456 (Figure 11). These are the roots of $3 x^{2}+5 x-3=0$ equation: $x_{1} \approx-2,138$ and $x_{2} \approx 0,456$.

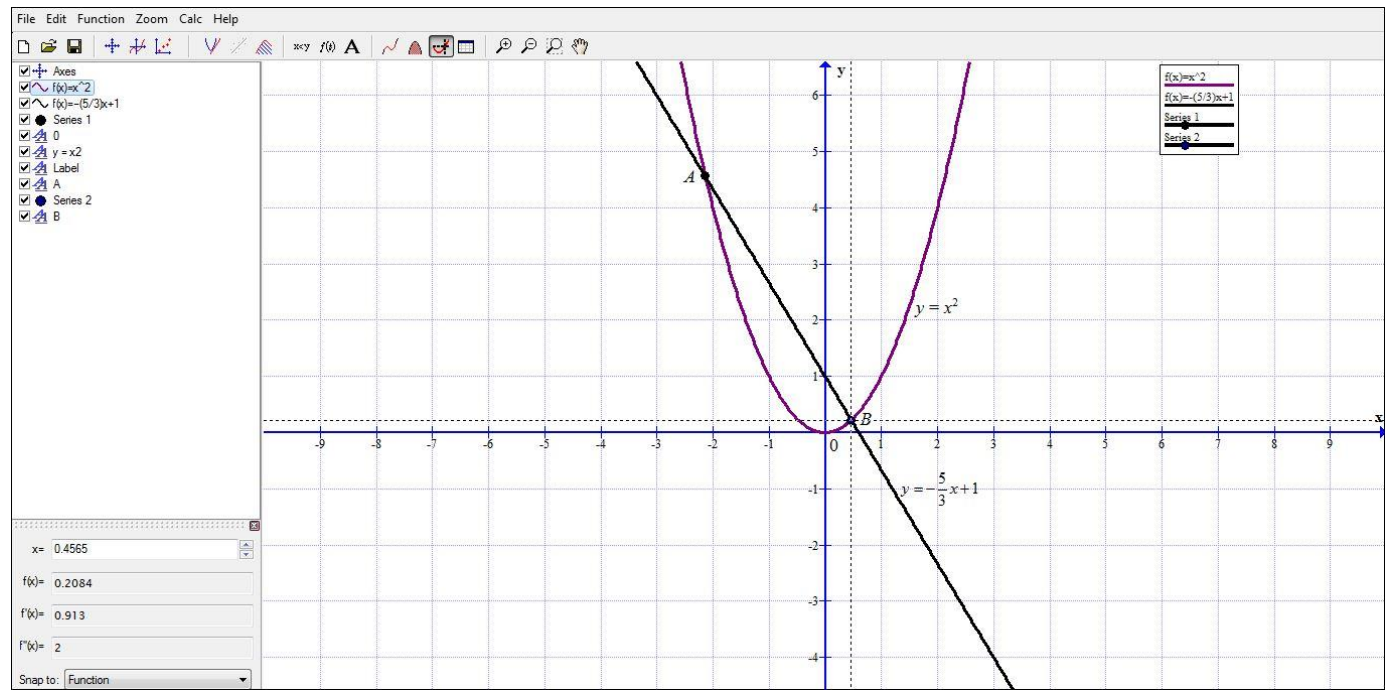

Figure 11. Graphs of $y=x^{2}$ and $y=-\frac{5}{3} x+1$ in Graph 4.4 
This question has been evaluated according to the criteria in Table 5 in the context of the ability to create graphs of appropriate functions and present the results using Graph 4.4:

Table 5. Deney sınıfında $3 x^{2}+5 x-3=0$ denklemi için değerlendirme

\begin{tabular}{|c|c|c|}
\hline $\begin{array}{c}\text { Level I } \\
\text { Wrong answer }\end{array}$ & $\begin{array}{l}\text { Level II } \\
\text { Partially correct answer }\end{array}$ & $\begin{array}{c}\text { Level III } \\
\text { Correct answer }\end{array}$ \\
\hline $\begin{array}{l}\text { Graph } 4.4 \text { makes it difficult to } \\
\text { draw graphs of appropriate } \\
\text { functions. }\end{array}$ & $\begin{array}{l}\text { Creates graphs of suitable } \\
\text { functions using Graph } 4.4 \text { notation, } \\
\text { but presents the result with help. }\end{array}$ & $\begin{array}{l}\text { Creates graphs of corresponding } \\
\text { functions using Graph } 4.4 \\
\text { notation and completely presents } \\
\text { the result. }\end{array}$ \\
\hline
\end{tabular}

\section{Findings}

The effect of Graph 4.4 software on students' ability to create and interpret function graphs was investigated. The frequency and percentage distributions of the answers in the experimental and control groups are given in Table 6.

Table 6. Distribution of the answers of the students in the experimental and control groups

\begin{tabular}{|c|c|c|c|c|c|c|c|c|c|c|c|c|c|c|}
\hline \multirow[b]{3}{*}{ Questions } & \multicolumn{2}{|c|}{$\begin{array}{c}\text { Number of } \\
\text { Students }\end{array}$} & \multicolumn{4}{|c|}{ Correct Answers } & \multicolumn{4}{|c|}{ Partially Correct Answersr } & \multicolumn{4}{|c|}{ Wrong Answers } \\
\hline & \multirow{2}{*}{$\mathrm{E}$} & \multirow{2}{*}{$\mathrm{C}$} & \multicolumn{2}{|c|}{$\mathrm{E}$} & \multicolumn{2}{|c|}{$\mathrm{C}$} & \multicolumn{2}{|c|}{$E$} & \multicolumn{2}{|c|}{$\mathrm{C}$} & \multicolumn{2}{|c|}{$\mathrm{E}$} & \multicolumn{2}{|c|}{$\mathrm{C}$} \\
\hline & & & $\mathrm{n}$ & $\%$ & $\mathrm{n}$ & $\%$ & $\mathrm{n}$ & $\%$ & $\mathrm{n}$ & $\%$ & $\mathrm{n}$ & $\%$ & $\mathrm{n}$ & $\%$ \\
\hline 1 & 24 & 22 & 8 & 33 & 4 & 18 & 14 & 58 & 10 & 45 & 2 & 8 & 7 & 32 \\
\hline 2 & 24 & 22 & 9 & 38 & 6 & 27 & 12 & 50 & 9 & 41 & 3 & 12 & 8 & 36 \\
\hline
\end{tabular}

Graph calculations, graphical modeling and graphical solution of problems are among the topics of the 8th grade mathematics curriculum. It is understood from Table 6 that teaching this subject using Graph 4.4 software in the experimental group is effective in learning the methods of calculating the function graphs based on drawing, graphs, and finding the roots of the function. When the answers given by the students to the two questions asked to both groups were examined, it was determined that the students in both groups had difficulty in creating graphs of functions as a paper and pencil activity. Examples of correct and partially correct answers from students' answer sheets are as follows:

Students who solved the first question correctly determined the area where the function is defined as $\mathrm{R} \backslash\{0\}$ (Figure 12):
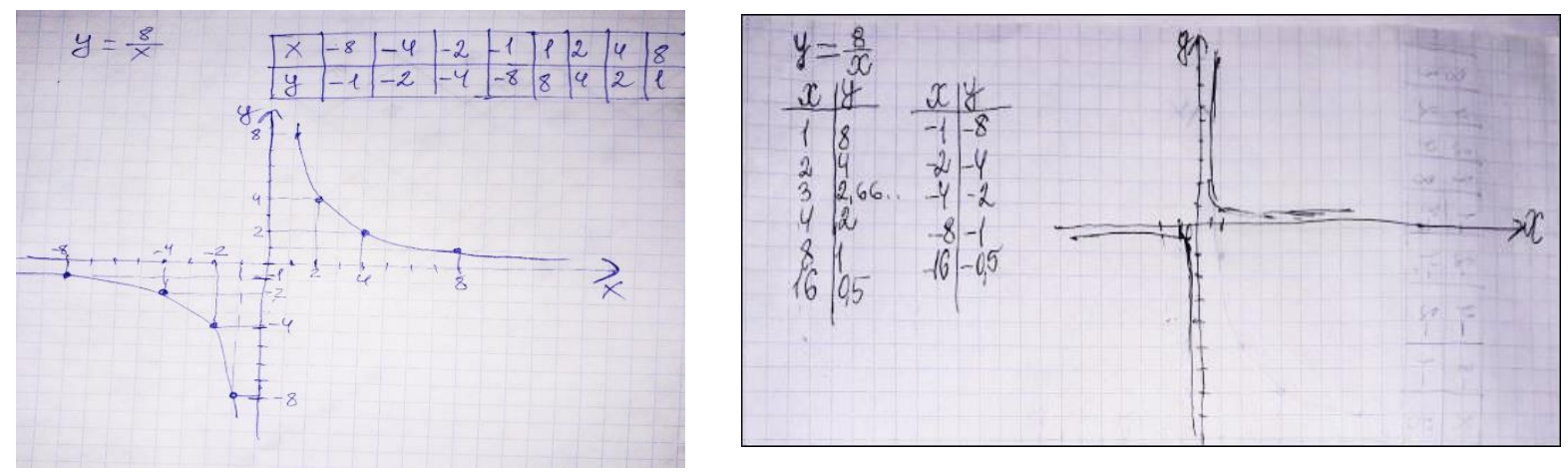

Figure 12. Students' answers to the first question. 
The students tried to show the solution to the second question in different ways (Figure 13):
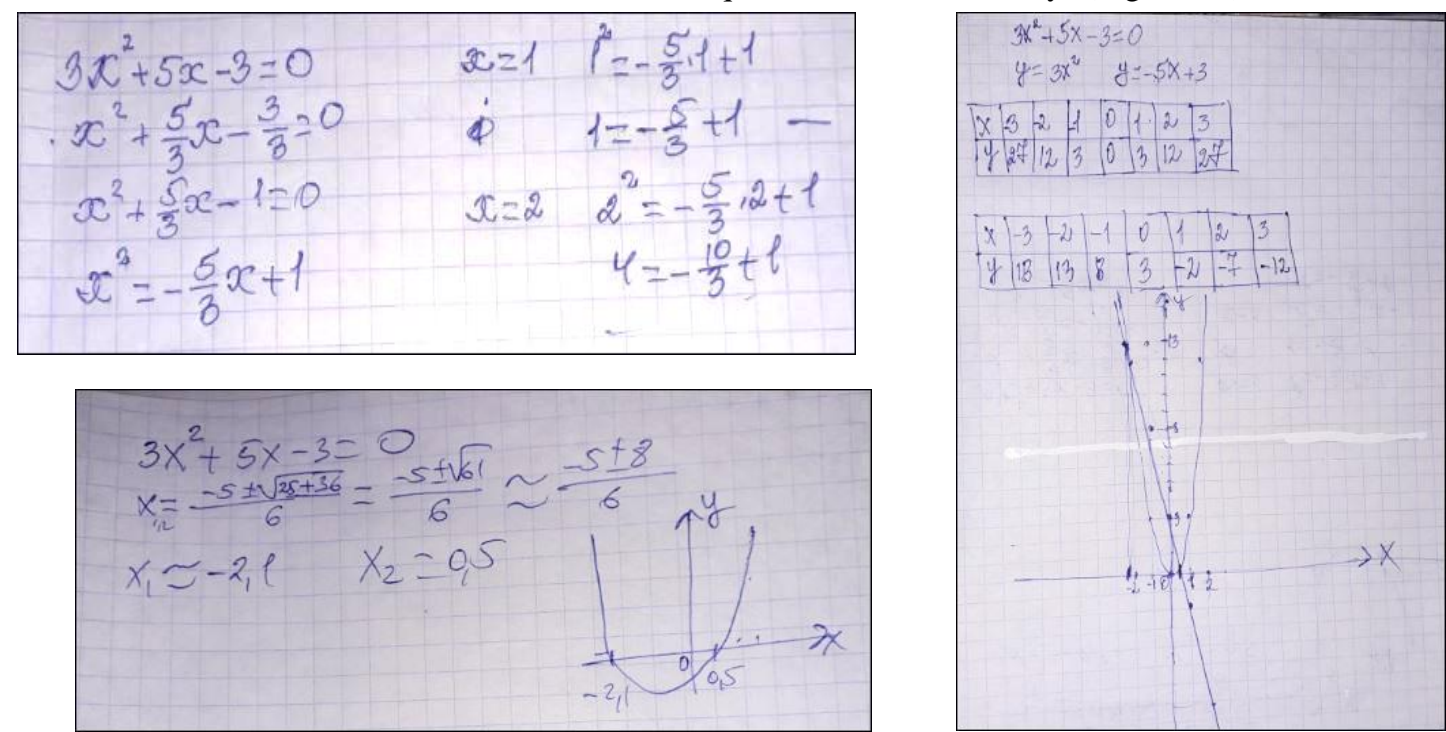

Figure 13. Students' answers to the first question.

The fact that the number of completely correct and partially correct answers of the experimental group $(n=42)$ is higher than that of the students in the experimental group $(n=29)$ and that the wrong answers are three times more in the control group shows that Graph 4.4 applications are effective. In other words, it was determined that the problem-solving skills of the students in the experimental group regarding graphic solution methods were $13 \%$ higher than the control classes. By expanding the scope of the research, it can be said that the proposed software creates a high motivation source for students and has a very important place in learning mathematics.

\section{Discussion, Conclusion and Suggestions}

In the research, the possibilities of developing graphic skills of middle school students in mathematics lessons were revealed. Detailed hypothesis tests were not conducted in this experimental study. The two groups were compared on the basis of the answers given to only two questions, their percentages were examined and comments were made about the effect of the software. Of course, the findings of such a limited study cannot be generalized. In order to generalize these results, it is necessary to use a larger sample and a research with more questions. Therefore, this study only presents sections from the practice in a secondary school in Baku. Depending on the limited results of the study, the use of Graph software in middle school mathematics lessons can be recommended to support students' learning about function graphs and solutions.

The ability to create and interpret function graphs is one of the important skills in the mathematics curriculum of secondary schools (mathematics curriculum (curriculum) for schools of the Azerbaijan Ministry of National Education (2013). The standards to be applied to the content line of algebra and functions in the 8th grade mathematics curriculum develop students' thinking skills and prepare them to understand real-life situations. The implementation of the standards (Qehramanova, Kerimov \& Huseynov, 2019) is carried out on the following skills:

$\checkmark$ Understands the solution of type equations $a x^{2}+b x=0, a x^{2}+c=0$ and $a x^{2}+b x+c=0$ as the abscissa of the intersection point of the function graphs $y=a x^{2}$ and $y=k x+d$;

$\checkmark$ It explores the roots of the quadratic equation by plotting the graphs of the corresponding functions on the same coordinate plane;

$\checkmark$ Creates a graph of suitable functions using electronic graph calculators and presents the results.

During the study, it was observed that the students did not fully master these skills. Several reasons for this are stated in the relevant literature:

$\checkmark \quad$ Lack of interest in mathematics for some students since primary school;

$\checkmark$ The transition of mathematical subjects from classroom to classroom from simple to complex;

$\checkmark$ As students age, their interests expand and as a result, less time is spent developing their mathematical knowledge and skills;

$\checkmark$ Poor use of new technologies by teachers, especially poor use of computer technology (Mehrabov \& Cavadov, 2007).

From this research, it is understood that the computer-assisted method chosen by the instructor plays an important role in developing students' skills of graphing and interpreting functions. The transition from memory school to thinking school requires every teacher to "create personality-oriented educational content based on 
competence" (Abbasov, 2019). That is, the knowledge acquired by the student today does not require an explanatory description of the learning materials as in traditional education. Here, the competencies that will occur in the student's personality are expressed. These skills are basically formed as a result of the teachinglearning process. One of the functions performed by the educational process is development (Adigozalov, 2012). Education should be guided to ensure development. Every teacher, including math teachers, should use the opportunities of the learning process to create favorable conditions for the development of students' skills. Building students' thinking skills starting from primary education will lead to the development of more complex cognitive skills (problem solving, judgment, proof, coordination, presentation) in the later stages of education. (Azerbaijan Ministry of National Education, 2013; Abbasov, 2019).

Technology is growing rapidly. This development also has a strong potential to change the direction of science and education. In order to keep up with the changes taking place, the abilities society expects of people must also change and develop. In this respect, it is necessary to ensure that mathematics education is carried out in accordance with the developments in science and technology. The use of ICT for learning and application of mathematics knowledge should be one of the basic requirements of today's mathematics courses. Using Graph 4.4 software in mathematics teaching will help students construct and develop their knowledge, skills and habits in the subjects they study, adapt them to real-life situations, and take responsibility for students' learning. 


\section{Fonksiyonlar Konusunun Öğretiminde Graph Yazılımının Kullanımı: Azerbaycan Örneği}

\section{Giriş}

Teknoloji hızla ilerliyor. Bu gelişme aynı zamanda eğitim sistemindeki uygulamaları da değiştirmektedir. Gerçekleşen değiş̧ikliklere ayak uydurmak için toplumun insanlardan beklediği beceriler de değişmekte ve gelişmektedir. $\mathrm{Bu}$ açıdan matematik eğitiminin bilim ve teknolojideki gelişmelere göre uyarlanması gerekmektedir. Bu gereksim nedeniyle bilgi ve iletişim teknolojileri (BİT) matematik derslerinde geniş uygulama alanı bulmaktadır. BİT'in matematik derslerinde kullanımı, öğrencilerin öğrendikleri konularda bilgi, beceri ve alışkanlıklarının oluşturulmasına ve geliştirilmesine, onları gerçek hayattaki durumlara uygulayabilmelerine yardımcı olmaktadır. Aynı zamanda ödevlerin öğrenciler tarafından bilgisayarda özel yazılımlar aracılığıyla yapılması, onları gelecekte daha zor ödevlerin yerine getirilmesine de teşvik etmektedir.

Günümüzde genel eğitim sistemlerinde "hafiza" okulundan "düşünme" okuluna geçişin sağlanması üzerine geniş çaplı çalı̧̧malar yürütülmektedir (Azerbaycan Başkanlık Kararnamesi, 2016). Artık, eğitimde yüksek kalite elde etmek için yeni öğretim teknolojilerinden, bilgisayar, akıllı tahta, internet ve diğer multimedya araçlarının kullanımı artık ciddi bir gereksinim haline gelmiştir. Öğretme-öğrenme sürecinde bilgi-iletişim teknolojilerinin kullanımı sadece bilgi, beceri ve alışkanlıklar edinilmesi için değil, aynı zamanda edinilmiş bilgi, beceri ve alışkanlıkların uygulanması alanında yaratıcı düşünen, rekabet edebilen, geleceği inşa edebilen insanların yetiştirilmesi için de gereklidir. Özellikle matematik derslerinde öğretme-öğrenme sürecini bilgisayarsız hayal etmek imkânsız hale gelmiştir. Bilgisayarlar iletişim kurmanın ve bilgiye ulaşmanın en etkili yolunu sağlamaktadır. Artık matematik derslerinde bilgisayar öğretmenin vazgeçilmez bir yardımcı aracı haline gelmiştir. Bilgi ve iletişim teknolojilerinin (BİT) kullanımı öğrencilere matematik eğitimi sırasında daha aktif olma firsatı yaratır ve aynı zamanda bilimsel bakış açısı, verilerle çalışma alışkanlıkları, diğer bilimlerin temellerinin farkına varmak için beceri ve alışkanlıklar oluşturur, öğrenilen konuyu dikkatli ve ilginç etmekle beraber uzun süre akılda kalmasını sağlar, yaratıcı olmaya ve araştırma yapmak için motivasyon kaynağı oluşturur (Tagiyeva, Hesenov ve Cebrayılzade, 2011). Matematik derslerinde, Mathcad-11, MATLAB-7, Scientific Work Place 5.0, Graph 4.4 gibi yazılımlar kullanılmaktadır.

Cebir ve fonksiyonlar öğrenme alanı, ortaokullarda öğretilen matematiğin beş temel öğrenme alanından (sayılar ve işlemler, cebir ve fonksiyonlar, geometri, ölçüm, istatistik ve olasılık) biridir (Azerbaycan Milli Eğitim Bakanlığı, 2006). Bu cebir öğrenme alanı diğer öğrenme alanları arasında bir köprü görevi görür. Cebir yoluyla, öğrenciler problemleri doğal bir dilden cebirde sembolik ve tam tersine çevirerek çözerler. Matematik çalışmasının ana alanlarından biri olan fonksiyonlar bölümü, öğrencilerin düzenliliklere, bağımlılıklara ve nicel ilişkilere hakimiyetine hizmet eder. Öğrenme alanında yer yer alan bu bölümün kapsamı üst sinıflarda genişlemektedir ve olağanüstü bir öneme sahiptir. Cebir ve fonksiyonlar konusu işlenirken çok sayıda problem analiz edilir, modellenir, çözülür ve sunulur. Araştırmalar, birçok lise öğrencisinin fonksiyon grafikleri oluşturmakta ve sonuçları sunmakta zorlandığını göstermektedir. Yeni müfredatta matematiksel araç ve teknolojilerin kullanılması, zorlukların üstesinden gelmek ve matematiksel becerileri geliştirmek için gereklidir (Azerbaycan Milli Eğitim Bakanlığı, 2013).

Bu çalışmada Graph 4.4 uygulama yazılımının özellikleri ve kullanımı (Johansen, 2012) ile ilgili bilgi verildikten sonra bir matematik sınıfında fonksiyonlar konusunun öğretiminde bu yazılımı kullanan öğrencinin fonksiyon grafiğini oluşturma ve yorumlama becerisi incelenmektedir. Dolayısıyla araştırma problemi aşağıdaki gibi belirlenmiş̧ir:

İkinci dereceden denklemlerin ve rasyonel ifadeli denklemlerin çözümü ve grafikleri konusunun öğretiminde kullanılan grafik 4.4 yazılımının öğrencilerin fonksiyon grafiğini oluş̧urma ve yorumlama becerisini etkilemekte midir?

\subsection{Graph 4.4 Yazlımının Teknik Özellikleri}

Graph 4.4 yazılımı öğrencilerin grafik becerilerinin oluşumunda vazgeçilmez imkânları olan mükemmel yazılımlardan biridir. Yazılımı kullanmadan önce, kullanım özelliklerini bilmek ve sonrasında kullanmak daha yararlı olacaktır. Graph 4.4 uygulaması, iki boyutlu kartezyen koordinat sisteminde grafikler oluşturmak için kullanılan açık kodlu bir yazılımdır. Fonksiyonların grafiklerini kurduktan sonra ona kolayca eklentiler de yapılabilir. Söz konusu yazılım aracılığıyla fonksiyonlar üzerinde bazı matematiksel hesaplar da yapılabilir. Yazılımın kapsadığı alan onun herhangi bir disk sürücüsünde tutulmasına ve bir yerden diğer bir yere kolayca taşınmasına imkân sağlamaktadır.

Yazılım paketi bilgisayara indirildiğinde, ekranda yazılımın ana sayfa penceresi aşağıdaki gibi açılacaktır (Şekil $1)$. 


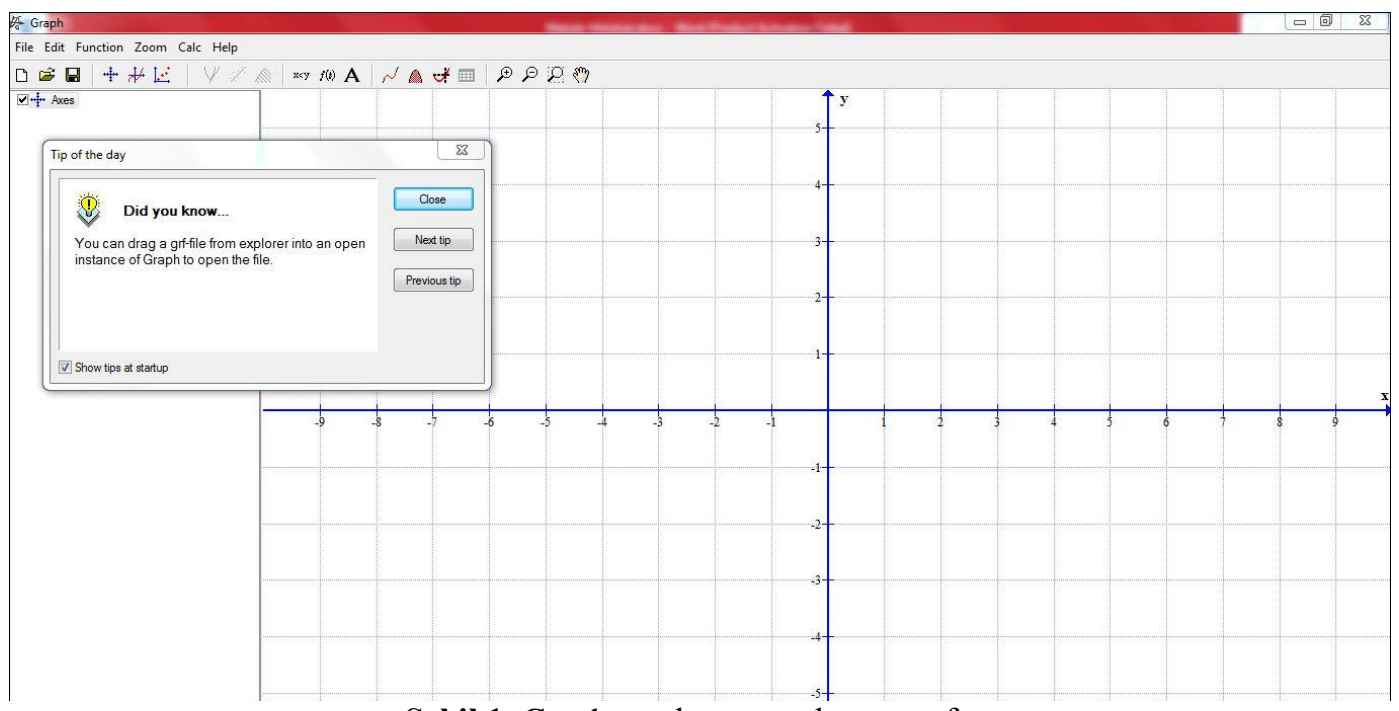

Şekil 1. Graph yazılımının çalışma sayfası

Pencerenin en üst kısmında başlık satırı, daha aşağıda ise menü çubuğu bulunmaktadır. Menü öğeleri alt menülerden ve araçlar panelinden oluşmaktadır. Pencerenin başlık satııının öğeleri diğer yazılım pencerelerine benzer, ancak bazı menü öğeleri ve alt menü öğeleri diğer yazılımlardan farklıdır. Pencereyi açarken, orta kısmında bir danışma nitelikli iletişim kutusu vardır. Bu pencerede ilgili soruyu cevapladıktan sonra yeni bir pencere açılacaktır. Sözkonusu pencerenin üç yönetim düğmesi vardır. Bunlardan ilki pencereyi kapatmak, diğerleri ise bir sonraki soruya ve önceki soruya geri dönebilme imkanı vermektedir.

Menünün "Dosya" (File) öğesinin seri ilk dört öğesi aynı karakterlidir. Beşinci "Resim olarak kaydet" ("Save as image) bölümü, aynı görüntülü yazılım sayfasını yeni bir adla hafıza taşır. Bu komut istendiğinde, komuta karşlık iletişim penceresi açılacaktır. Sözkonusu pencerenin "Dosya adı" (File name) bölümüne, dosya adı yazılacaktır. Bu menünün İçe Aktar (Import) isimli altıncı öğesi ise, yazılımın bizzat kendisinden diğer görüntülerin indirilmesi içindir.

Ana menüdeki ikinci öğe "Düzenle" (Edit) dir. Bu öğe aracıllğıyla çizilen grafikler düzenlenir, hatalar düzeltilir. Bu öğenin de alt menü komutları diğer uygulama yazılımlarındakı gibidir.

Sıradakı menü öğesi "İşlev" (Function) diye geçmektedir, ana görevi fonksiyonların grafiklerinin oluşturulmasını sağlamaktır. Menü öğesinde en sık kullanılan alt öğe "İşlev Ekle" (İnsert function») öğesidir. $\mathrm{Bu}$ öğe kullanıldığı zaman ekranda aynı isimli iletişim kutusu açılacaktır. İletişim kutusunun "İşlev türü" (Function type) bölümünde fonksiyon tipi olarak, üç tip fonksiyondan biri standart, parametreli veya polar fonksiyon olması tercih edilir. "Fonksiyon denklemi" (Function equation) alanına ise karşlık gelen fonksiyonun denklemini yazmak gerekir.Açılan iletişim kutusunda, fonksiyonun grafiğinin oluşturulacağı aralık ve adımı, grafiği gösterme tipi, rengi, boyutu, işaret tipi, rengi, boyutu ve diğer parametreler seçilmesi gerekir. Ardından, OK komut düğmesine basıldığında grafik otomatik olarak ayarlanır. Bu iletişim kutusunda yardımcı düğme ve komutu iptal edecek düğme seçeneği de vardır. Bu arada bir koordinat sisteminde bir kaç fonksiyonun için grafiklerin oluşturulabileceği mümkün. Bu ise fonksiyonların grafiklerinin öğrenilmesi sırasında karşılaştırmak için önemli bir etkendir (Şekil 2).

İkinci alt menü ise, "Tangent ekle/Normal" (Insert tangent/normal) ismiyle geçmekle verilen noktaya dokunmak, kesmek veya dikey çekmek için kullanılır.

Bu yazılım, sadece grafiğin oluşturulmasında değil, denklem probleminin grafiksel yöntemle çözümünde de başarılı bir şekilde kullanılabilir. Yazılımı kullanırken denklem problemine özgü bilinmeyenlerin fazla olması, değişenin derece boyutunun karmaşıklı̆̆ı, vb. çözüm sırasında zorluk oluşturmaz. $\mathrm{Bu}$ tür denklemlerin geleneksel yöntemle çözümlenmesi için harcanan sürenin, Graph yazılımı kullanılarak harcanan süreden çok daha fazla olduğu bilinmektedir. Kurulumun tam yerine getirilme doğruluğunu da buraya eklersek, bu yazılımın eşsiz bir avantajının olması sonucuna varırız. 


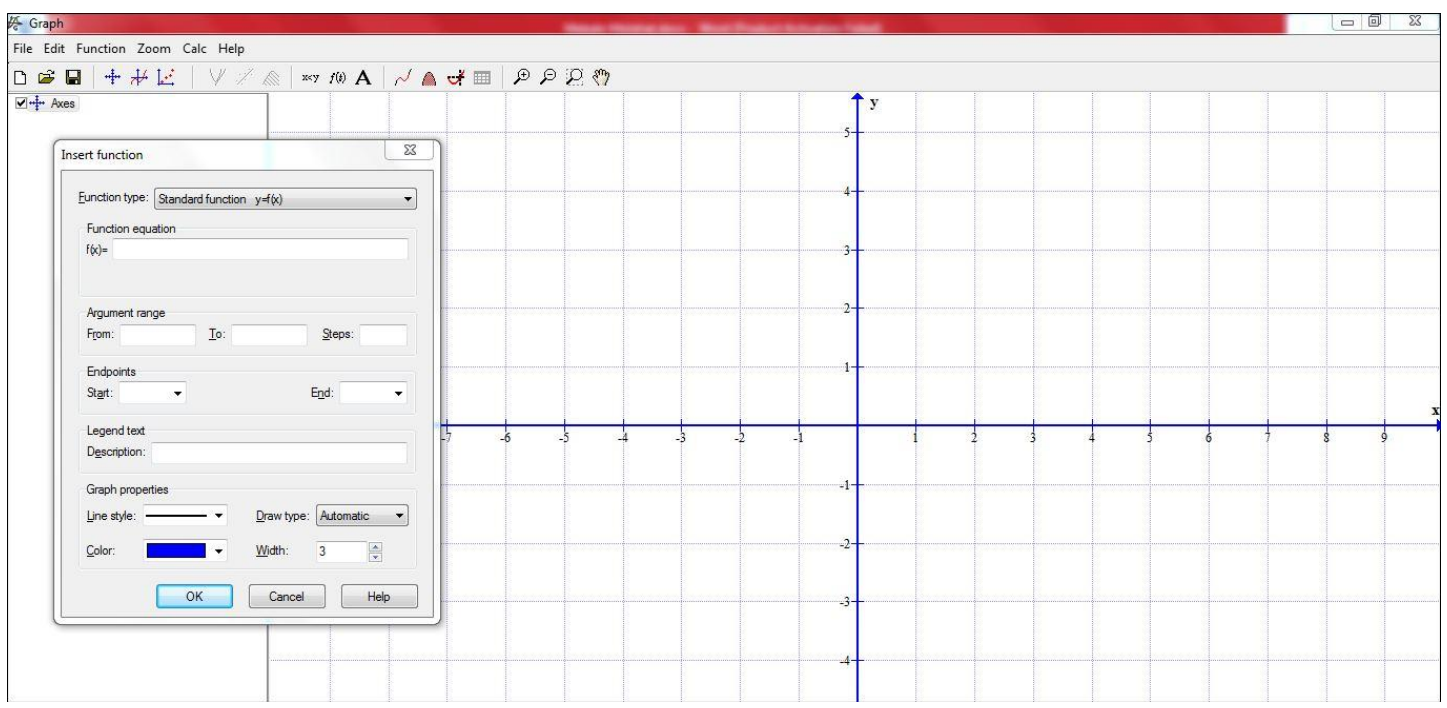

Şekil 2. Graph yazılımının "Function” menüsünün “Insert function” penceresi

Sonraki üçüncü paragraf "Gölgeleme Ekle” (İnsert shading)dir. Bu bölüm de geniş imkanlar sağlamaktadır. Şöyle ki, eşitsizliklerin çözümünde, aralıkların gölgelenmesi büyük önem taşımaktadır. Geleneksel yöntem çok zamanalıcı ve dağınık görülen bir işdir. Bunun yanında ek olarak, bilinmeyenlerin sayısı ve gölgelenecek alanlar fazla olduğunda, dağınıklık daha belirgin hale geliyor. Ancak bu yazılımı kullanmak sadece eksiklikleri ortadan kaldırmaz, aynı zamanda yeni firsatlar yaratmaya da yardımcı olur. Graph 4.4 uygulamasının kullanımı kartezyen koordinat sisteminde gölgelemeyi altı yönde yapmaya olanak sağlamaktadır:

1. Fonksiyonun grafiği ile $O X$ ekseni arasındaki alanın gölgelenmesi;

2. Fonksiyon grafiğinin alt kısmının gölgelenmesi;

3. Fonksiyonun grafiğinin üst kısmının gölgelenmesi;

4. Fonksiyonun grafiği ile $O Y$ ekseni arasındaki alanın gölgelenmesi;

5. Fonksiyonun grafiğinin iç kısmının gölgelenmesi;

6. Fonksiyonların grafiklerarası mesafesinin gölgelenmesi (Abdullayeva, 2012).

Fonksiyonun türevinin grafiğini oluşturmak için "Insert $f^{\prime}(x)$ ", grafikler üzerinde noktaları belirtmek için "İnsert noktası series" (Insert point series»), yeni fonksiyon grafikleri yapmak için «İnsert relation», noktaların isimlendirilmesi, formülleri yazmak için "Insert text label” (İnsert text label), özel fonksiyonlar girmek için "Özel işlevler/sabitler" (Custom functions/constants) isimli "İşlev" (Function) menüsünü alt menülerini kullanabilirsiniz. Kartezyen koordinat sisteminde, grafiklerin boyutlarını değiştirmek için "Zoom”, hesaplama sırasında "Kireç" (Calc) uygulamalarını kullanırken sorunlar ortaya çıktığında yardım almak için "Yardım" (Help) menülerinin kullanımı kullanıcı için daha iyi bir ortam oluşturur.

Örnek 1: $\left\{\begin{array}{l}2 x+y=1 \\ 2 x-y=3\end{array}\right.$ denklem sistemini grafiksel olarak çözün. İfadesinde bulunan her bir denklemin grafiğinin $O X$ ve $O Y$ eksenleri ile kesişim noktalarını kaydedin (İsmayılova, 2014).

Çözüm: Denklem sistemini Graph 4.4 yardımıyla çözelim.

İlk olarak, sistemin her iki denklemi y'ye göre yeniden düzenlenir: $\left\{\begin{array}{l}y=-2 x+1 \\ y=2 x-3\end{array}\right.$

"İşlev" menüsünün "Fonksiyon ekle" alt menüsündeki "Insert equation" alanına $-2 x+1$ ve $2 x-3$ ifadelerini programlama dilinde, yani $-2 * x+1$ ve $2 * x-3$ şeklinde $f(x)$ 'ın karşısındakı alana yazalım. Her denklem için grafiğin oluşturulacağı aralık, adım, grafiğin gösterilme tipi, renk, kalınlık, uygun parametrelerle işaretleyici vb. seçilir ve grafikler sistemde otomatik olarak kurulmuş olacak. Diğer seçenekleri kullanarak her bir denklemi ona uygun grafiğin üzerinde belirtmek, grafiklerin kesişme noktasını, her grafiğin $O X$ ve $O Y$ eksenleri ile kesişme noktasının koordinatlarını bulmak ve kolaylıkla doldurmak mümkün. Farenin okunu grafiklerin kesişme noktasının üzerine koyarsak, o noktanın koordinatlarının 1 ve -1 olduğunu görebiliriz. Böylece, düz çizgilerin kesişme noktasının koordinatları $A(1,-1)$ olarak bulunur. Her bir grafiğgin koordinat oklarıyla kesişme noktasına fareyi yeniden getirerek, ekranın sağ alt köşesinde o noktanın koordinatlarını görebilirsiniz. $2 x+y=1$ denkleminin grafiği $O X$ ekseni $B(0,5 ; 0), O Y$ eksenini ise $C(0 ; 1)$ noktasında keser.

$2 x-y=3$ denkleminin grafiği $O X$ eksenini $D(1,5 ; 0), O Y$ eksenini ise $K(0 ;-3)$ noktasında keser (Şekil 3$)$. 


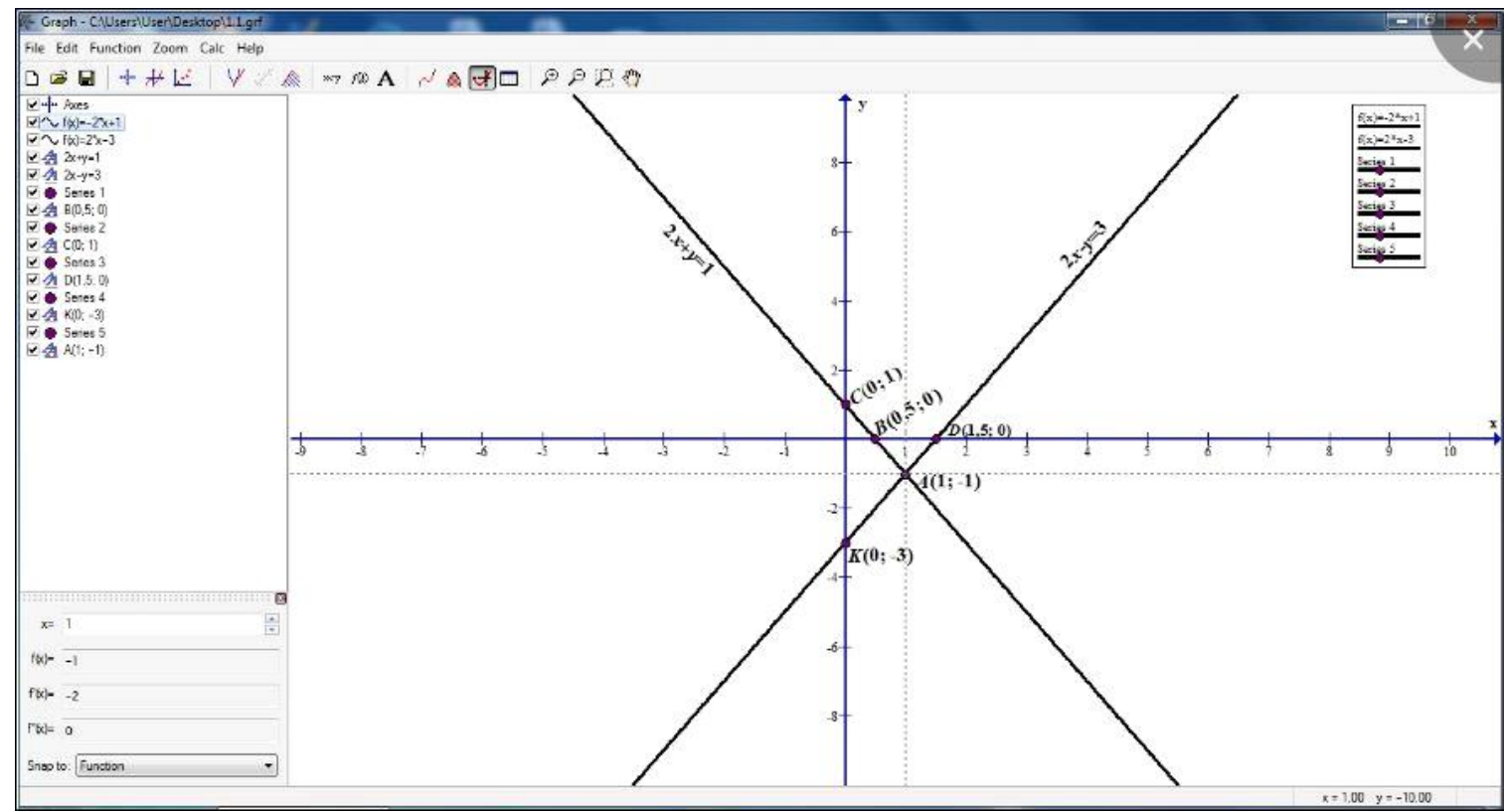

Şekil 3. Denklem sisteminin grafik yöntemle çözümü

Örnek 2. Denklem sistemini grafiksel olarak çözün: $\left\{\begin{array}{l}3,5|x|-y=2 \\ y+x^{2}-6=0\end{array}\right.$ (Merdanov, 2010).

Çözüm: Sistemin her iki denkleminde $y$ 'i $x$ olarak ifade edelim: $\left\{\begin{array}{l}y=3,5|x|-2 \\ y=6-x^{2}\end{array}\right.$

Graph 4.4 yazılımının "İşlev menüsünün "Insert function" alt-menü öğesindeki "Denklemi ekle" alanına önce $3.5|x|-2$ denklemini $f(x)=3,5 \operatorname{abs}(x)-2$ programlama dilinde yazınız. Daha sonra denkleme göre grafiğin oluşturulacağı aralı̆̆ı, adımı, grafiğin görüntüleme tipini, rengi, kalınlığı, uygun parametrelerle işaretleyiciyi seçip otomatik olarak sistemde grafiğimizi oluşturalım. Benzer şekilde, 6- $x^{2}$ denklemini $f(x)=6-x^{2}$ programlama dilinde ayarladıktan sonra parametreleri seçerek grafiği oluşturmanız mümkün (Resim 4). Grafikler $A(1,5716 ; 3,5006)$ ve $B(-1,5716 ; 3,5006)$ noktalarında kesişiyor. Böylece, $(1.57,3.51)$ ve $(-1.57 ; 3.51)$ çiftleri denklemin yaklaşı çözümü olacaktır.

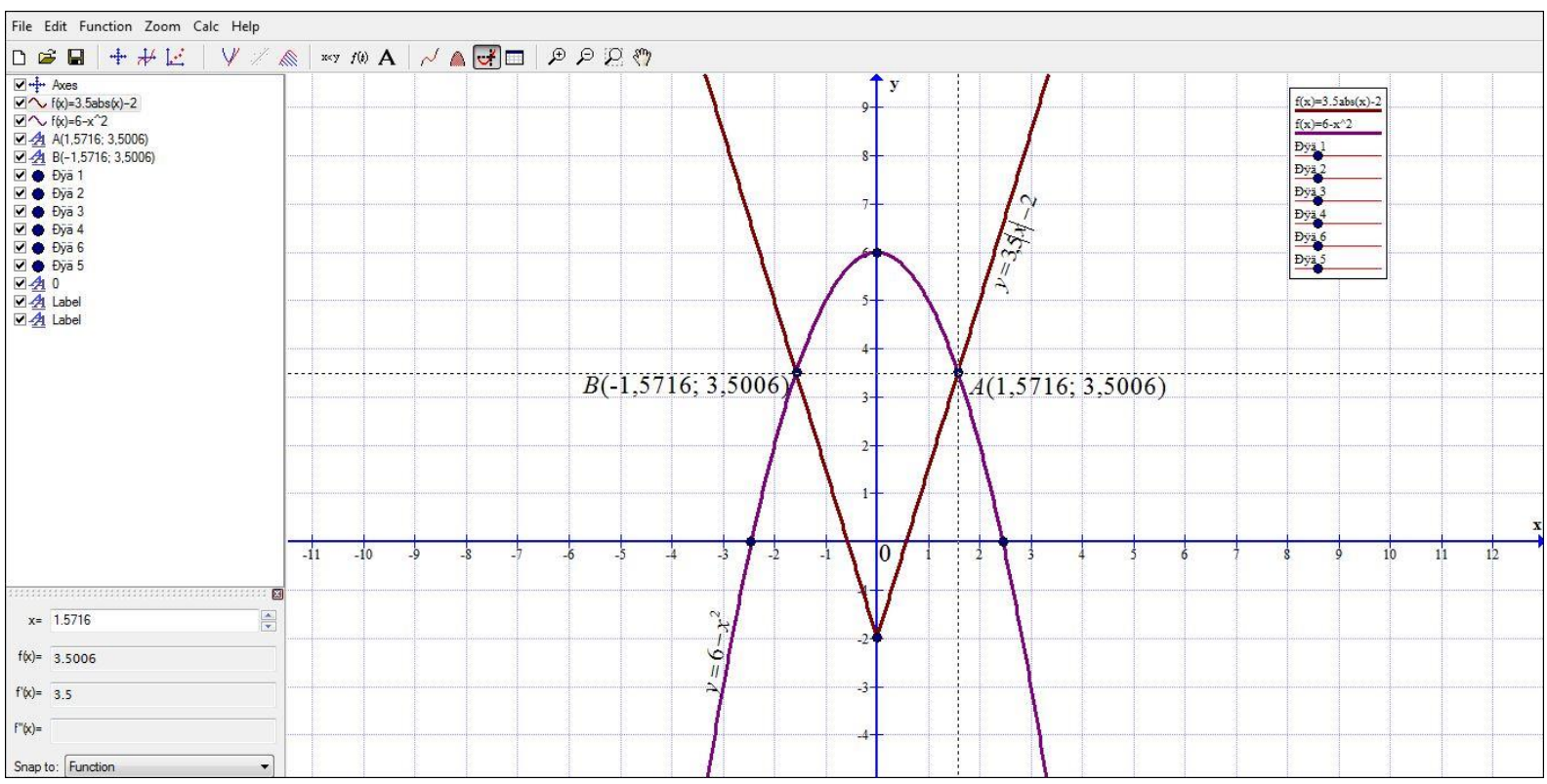

Şekil 4. Denklem sisteminin grafik yöntemle çözümü

Örnek 3: $y=e^{x}, y=0, x=0, x=1$ ile sınırlanmış şeklin alanını hesaplayın (Merdanov, 2009).

Çözüm: Graph 4.4 yazılımının «Function» menüsünün «Insert function» alt-menü öğesindeki «İnsert equation» alanına önce $y=e^{x}$ ve $y=0$ denklemini programlama dilinde yazalım. 
Grafikler, aralık, adım, grafik ekran tipi, renk, kalınlık, uygun parametrelerle işaretleyici seçilerek sisteme otomatik olarak ayarlanır (Resim 5). Ardından, «Function» öğesinin "Insert relation” alt menü öğesindeki "Edit relation" alanına $x=0$ ve $x=1$ olduğunu girelim. "Function" öğesinin "Insert label" alt menüsü içindeki "Insert text label" penceresini kullanarak, bükülmüş trapezi tanımlayabilir, grafiklerin üzerinde formülleri yazabilir veya herhangi bir sembolü işaretleyebilirsiniz. Elde edilen bükülmüş trapezin alanını hesaplamak için "Calc" menüsünün "Area” alt menüsünde $[0 ; 1]$ verisi girilir ve alan otomatik olarak hesaplanır. Böylece talep edilen alan 1.7183 veya (e-1)’e eşittir.

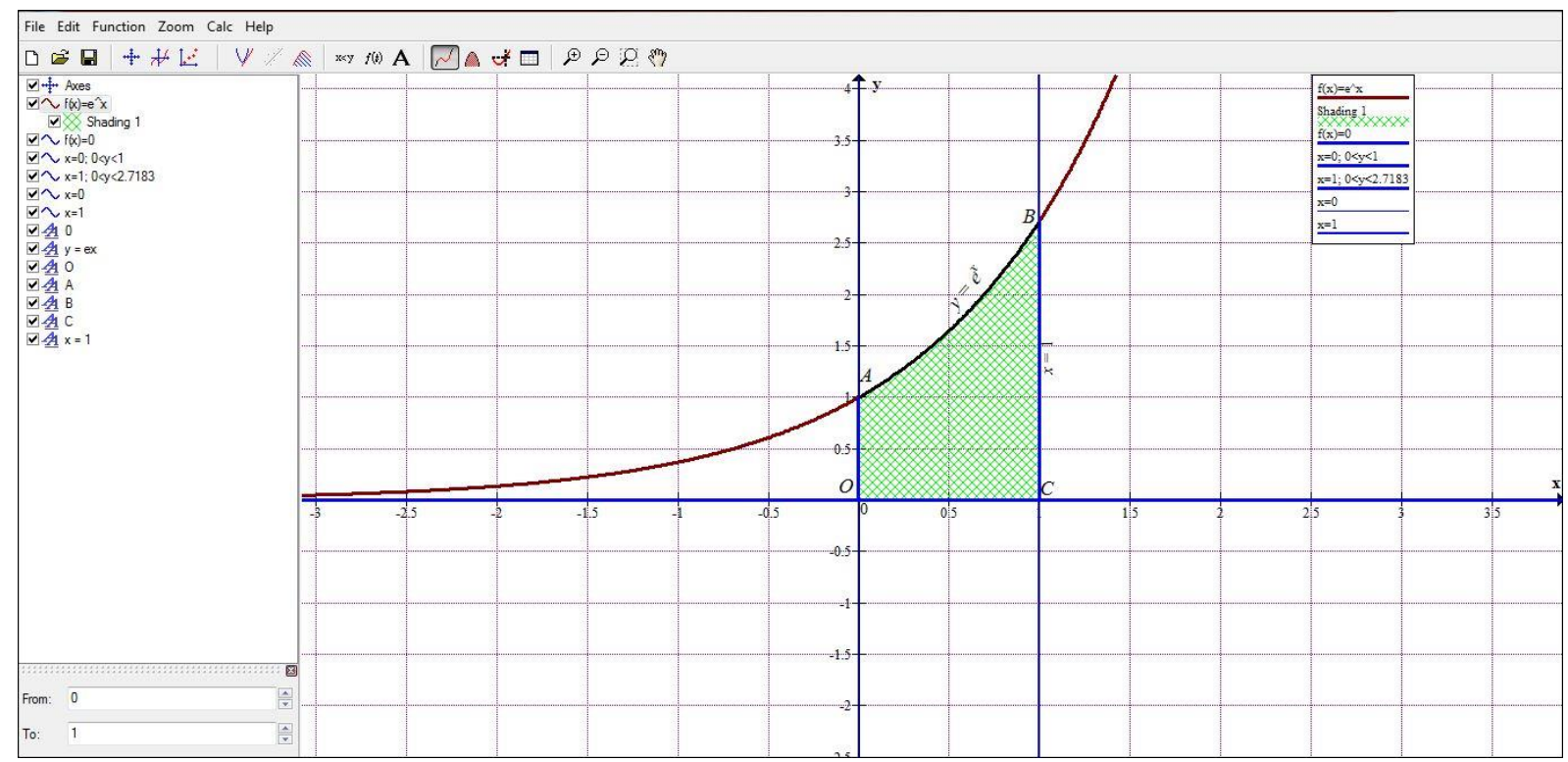

Şekil 5. Bükülmüş trapezin alanının hesaplanması

Örnek 4. $y=\frac{2}{x}, y=0, x=1, x=4$ doğrularıyla sınırlanmış şeklin alanını hesaplayın (Merdanov, 2009).

Çözüm: Benzer şekilde, Graph 4.4 yazılımının "Function” öğesinin "Insert function” alt menüsündeki "Insert equation" alanına $y=2 * 1 / x$ ve $y=0$ fonksiyonlarını programlama dilinde girip uygun ayarları seçdikden sonra grafiğimizi oluşturalım (Resim 6). "Calc” öğesinin “Alan” alt menü öğesinde [1;4] verilerini girmekle alanın yaklaşık 2.7726'a eşit olduğunu görebiliriz.

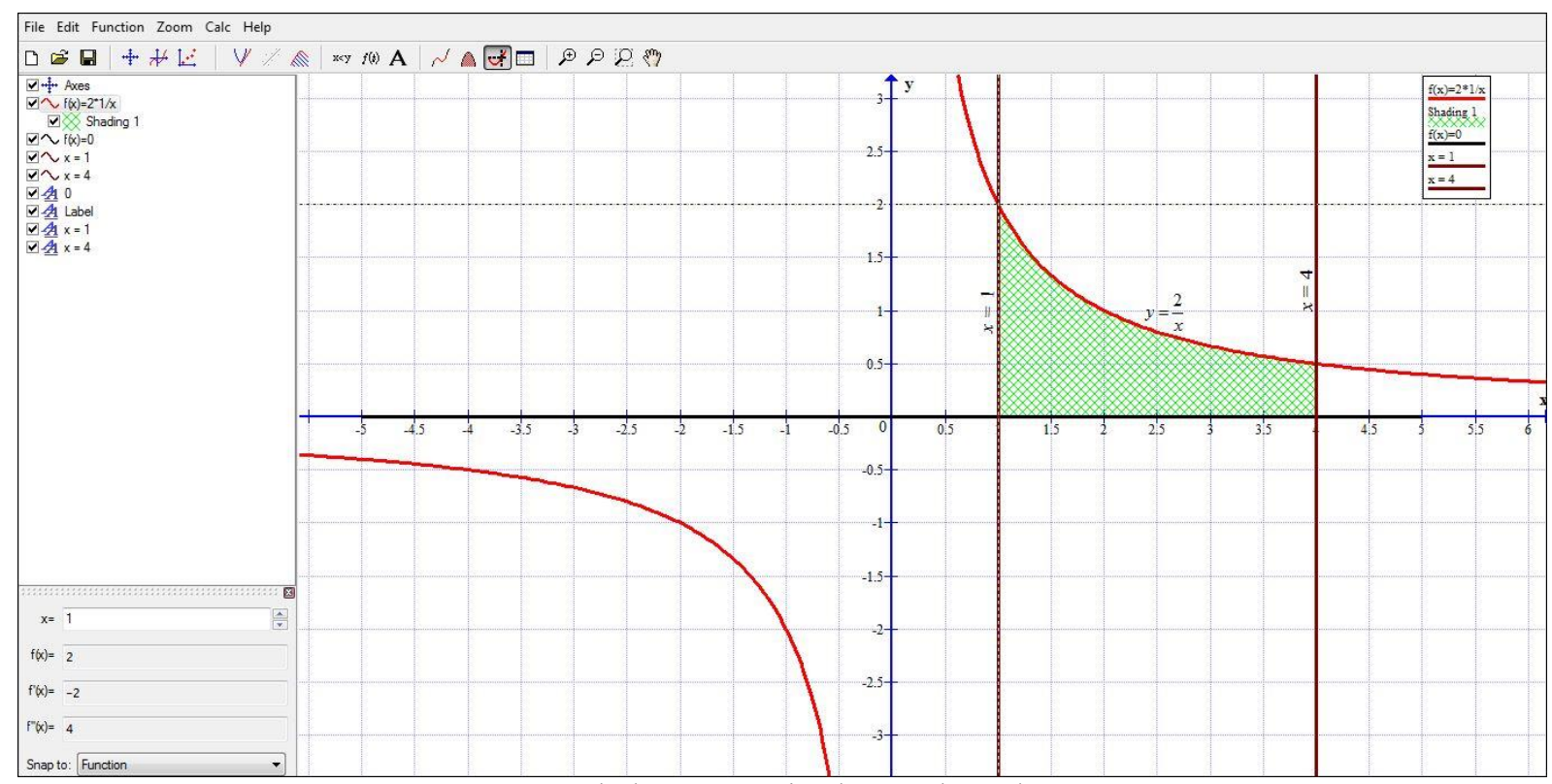

Şekil 6. Bükülmüş trapezin alanının hesaplanması

Örnek 5. $y=3 x-x^{2}, y=0$ çizgilerile sınırlanmış şeklin alanını hesaplayın (Merdanov, 2009). 
Çözüm: Öncelikle, grafiklerin kesişme noktalarının eksenlerini bulalım. Bunun için $3 x-x^{2}=0$ denklemi çözelim. Denklemin çözümü $x_{1}=0$ ve $x_{2}=3$ olarak sonuçlanır. Ardından benzer şekilde, Graph 4.4 yazılımının "Function” menüsünün "Insert function” alt menüsündeki "Insert equation” alanına $y=3 * x-x^{\wedge} 2$ və $y=0$ fonksiyonlarını girip uygun ayarları seçdikden sonra grafiğimizi oluşturalım (Resim 7). "Calc" menüsünün "Area” alt menü öğesinde [0;3] verilerini girmekle alanın yaklaşık 4.5'e eşit olduğunu elde ederiz.

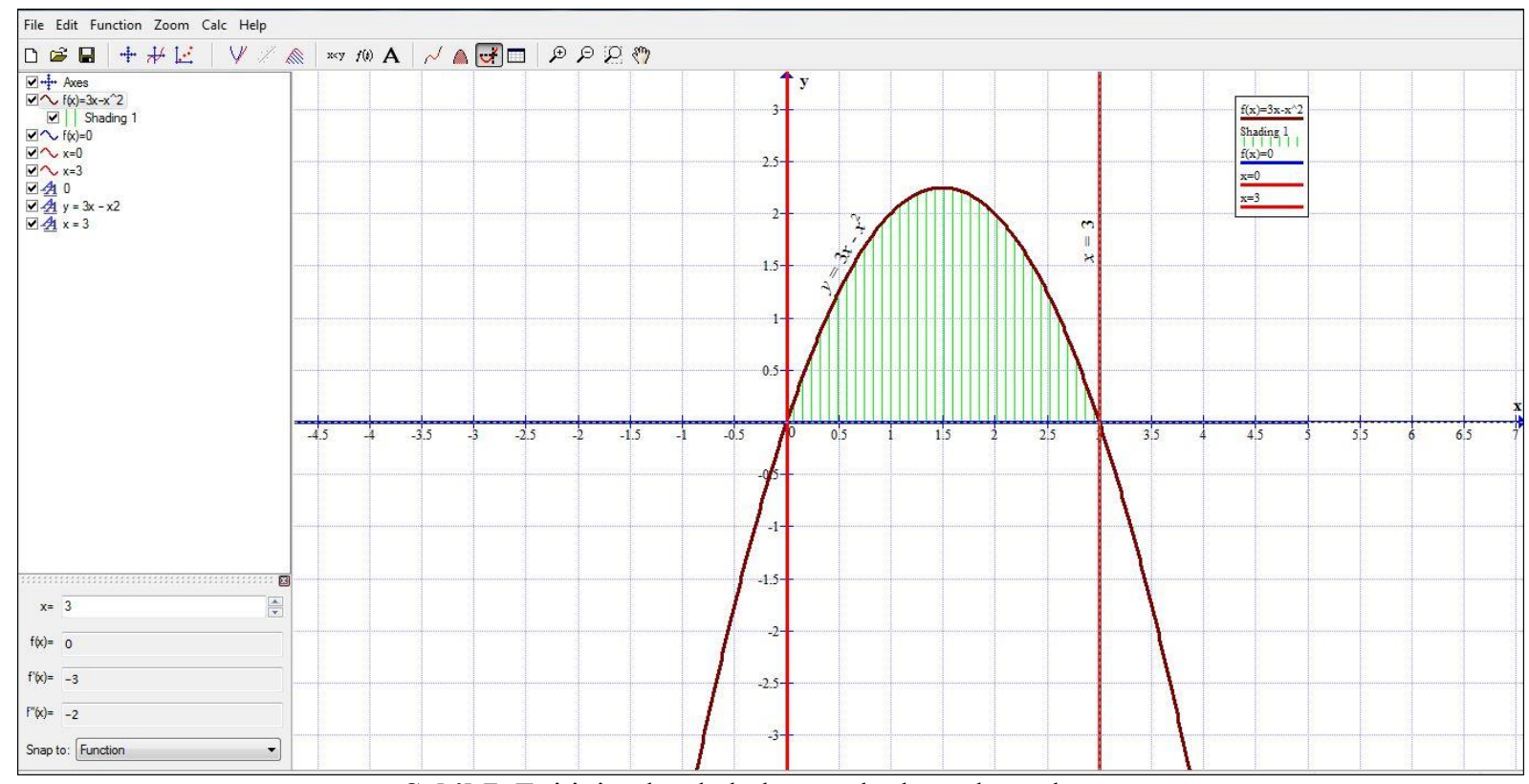

Şekil 7. Eğitinin altında kalan taralı alanın hesaplaması

\section{Yöntem}

\subsection{Araştırma Tasarımı ve Katılımcılar}

Araştırma 2017-2018 akademik yılında Bakü'de bir ortaokulda gerçekleştirildi. Çalışmadan önce Bakü'deki bazı ortaöğretim okullarında matematik öğretmenlerinin dersleri gözlemlenmiş, yaklaşık 30 (n <30) matematik öğretmeni ve 180 sekizinci sınıf öğrencisi ile görüşülmüş ve bir anket uygulanmıştır. Anket öğrencilere «Matematiği nasıl öğrenmek istersiniz?» diye bir soru soruldu. Öğrencilerin \% 85'-i «Bilgisayar teknolojisi yardımıyla öğrenmek istiyorum» yanıtını vermiştir.

Graph 4.4 yazılımı ortaöğretim 8. sınıfta matematik öğretiminde kullanılırsa, öğretim kalitesinin artacă̆1, öğrencilerin matematiği öğrenmeye motive edileceği ve sonuç olarak daha fazla grafik oluşturma ve yorumlama becerisi geliştirecekleri hipotezi ile çalışma başlatıldı. Hipotezin geçerliliği deneysel bir çalışma ile test edilmiş ve sonuçlar karşılaştırılmıştır.

Araştırma deney-kontrol deseniyle yürütülmüştür. Bakü'de 21 No'lu ortaokulun iki ayrı 8.sınıfı ele alındı, bunlardan biri rastgele kontrol grubu $(n=22)$ diğeri de deney grubu $(n=24)$ olarak tanımlandı. Sekizinci sınıf matematik müfredatının alt öğrenme alanları olan ikinci dereceden denklemler ve rasyonel denklemler konusu deney grubunda Graph 4.4 yazılımı kullanılarak anlatıldı. Kontrol grubunda ise bu konuların öğretimi mevcut matematik kitabı takip edilerek akıllı tahtanın kullanılmadığı bir sınıfta yapıldı.

Öğretim yılının ilk yarısının sonunda, deney ve kontrol sınıflarındaki grafik becerileri karşılaştırmak için bir test uygulanmıştır. Bu deney sınıf tarafindan Graph 4.4 kullanılarak, kontrol sınıfı ise kağıt ve kalem kullanılarak yapıldı. Testte kullanılan sorular aşağıdaki gibi tanımlanmıştır:

Soru 1. $y=\frac{8}{x}$ fonksiyonunun tayin alanını bulun ve grafiğini oluşturun.

Soru 2. $3 x^{2}+5 x-3=0$ denklemini grafik yöntemi ile çözün (Qehramanova, Kerimov ve Hüseynov, 2015).

\subsection{Veri Analizi}

Hem kontrol, hem de deneysel sınıflarda öğrencilerin yazılı cevapları tam doğru, kısmen doğru ve yanlış şeklinde üç kategoride puanlanarak analiz edilmiştir. 
Kontrol grubunda birinci soruya verilen cevapların değerlendirilmesi için kullanılacak ölçütler aşağıdaki gibi belirlenmiştir:

$y=\frac{k}{x}$ formülü ile oluşturulan funksiyon ters oransal fonksiyon denir. Burada $x$ serbestçe değişkendir $x \neq 0$ ), $k$ sıfırdan farklı rakamdır. $y=\frac{8}{x}$ formülü ile sunulan fonksiyon ters orantılı bir işlev olaraktan, alan, sıfır dışındaki tüm gerçek sayılar kümesidir. Ters orantılı bir fonksiyonun grafiğine hiperbol denir ve iki daldan oluşur. $k=8>0$ olduğundan $x$ ve $y$ eşit şartlı olaracak ve hiperbol dalları koordinat düzleminin I. ve III. bölgelerinde yer alacaktır. $y=\frac{8}{x}$ fonksiyonun grafiğini oluşturmak için ilk önce değerler tablosu oluşturulmaktadır (Tablo 1), sonrasında grafik oluşturumaktadır (Resim 8):

Tablo 1. $y=\frac{8}{x}$ fonksiyonu için değerler tablosu

\begin{tabular}{|l|l|l|l|l|l|l|l|l|l|}
\hline$X$ & -8 & -4 & -2 & -1 & 0 & 1 & 2 & 4 & 8 \\
\hline$Y$ & -1 & -2 & -4 & -8 & tayin olunmayor & 8 & 4 & 2 & 1 \\
\hline
\end{tabular}

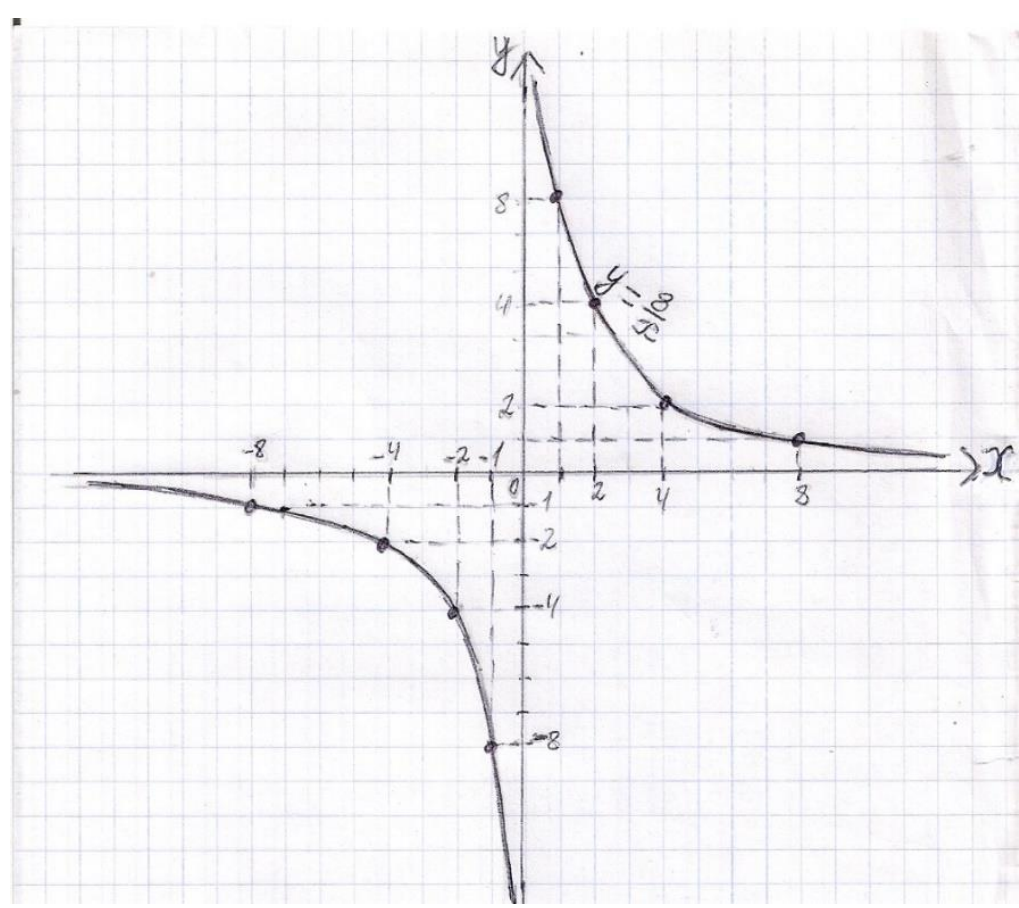

Şekil 8. $y=\frac{8}{x}$ fonksiyonunnun grafiği.

Yalnız fonksiyonun grafiğini doğru oluşturan öğrencilerin cevabı «kısmen doğru cevap», fonsiyonun belirlenmiş alanını yazmayan ve programı doğru ayarlamayan öğrencilerin cevapları da «yanlış cevap» olarak değerlendirilmiştir. Öğrenciler, «ters orantılı bağımlılı̆̆ı grafiksel olarak sunma» (Gehramanova, Kerimov ve Huseynov, 2019) becerilerinin düzeylerini tanımlayan değerlendirme listelerinde değerlendirildi (Tablo 2).

Tablo 2. Kontrol sınıfı sunum becerileri için değerlendirme

\begin{tabular}{c|c|c}
$\begin{array}{c}\text { I seviye } \\
\text { yanlış cevap }\end{array}$ & $\begin{array}{c}\text { II seviye } \\
\text { kısmen doğru cevap }\end{array}$ & $\begin{array}{c}\text { III seviye } \\
\text { doğru cevap }\end{array}$ \\
\hline
\end{tabular}

\begin{tabular}{l|l|l}
\hline $\begin{array}{l}\text { Ters orantılı bağımlılıkları çizmek } \\
\text { zordur. }\end{array}$ & $\begin{array}{l}\text { Yardımla grafiksel olarak } \\
\text { orantılı bağımlılı̆̆ı sunar. }\end{array}$ & $\begin{array}{l}\text { Ters orantılı bağımlılık grafiksel } \\
\text { olarak serbestçe sunulmaktadır. }\end{array}$ \\
\hline
\end{tabular}

Burada: I. seviye yanlış cevapları, II. seviye doğru fakat eksik cevapları, III. seviye tam doğru cevapları gösterir.

Kontrol grubunda ikinci soruya verilen cevapların değerlendirmesi için kullanılacak ölçütler aşağıdaki gibi belirlenmiştir:

Doğru ve eksiksiz cevap: $3 \boldsymbol{x}^{\mathbf{2}}+\mathbf{5} \boldsymbol{x}-\mathbf{3}=\mathbf{0}$ denkleminin $3 \boldsymbol{x}^{\mathbf{2}}=\mathbf{- 5} \boldsymbol{x}+\mathbf{3}$ biçiminde yazılması ve her iki tarafının 3-e bölünmesi. $x^{2}=-\frac{5}{3} x+1$ Aynı koordinat düzleminde $y=x^{2}$ ve $y=-\frac{5}{3} x+1$ fonksiyonların grafiğginin oluşturulması (Resim 9). Her bir işlev için bir değer tablosunun derlenmesi (Tablo 3): 
Tablo 3. $y=x^{2}$ ve $y=-\frac{5}{3} x+1$ fonksiyonlar için değer tablosu

\begin{tabular}{cccccccc}
\hline$X$ & -3 & -2 & -1 & 0 & 1 & 2 & 3 \\
\hline$y=x^{2}$ & 9 & 4 & 1 & 0 & 1 & 4 & 9 \\
\hline
\end{tabular}

\begin{tabular}{cccc}
\hline$x$ & -3 & 0 & 3 \\
\hline$y=-\frac{5}{3} x+1$ & 6 & 1 & -4 \\
\hline
\end{tabular}

$y=x^{2}$ parabol ile $y=-\frac{5}{3} x+1$ düz çizginin kesişme noktalarının apsisi verilen denklemin kökü olacaktır. Düz çizgi parabolle kesiştiği için, denklemin iki farklı kökü vardır: $x_{1} \approx-2,2$ ve $x_{2} \approx 0,5$.

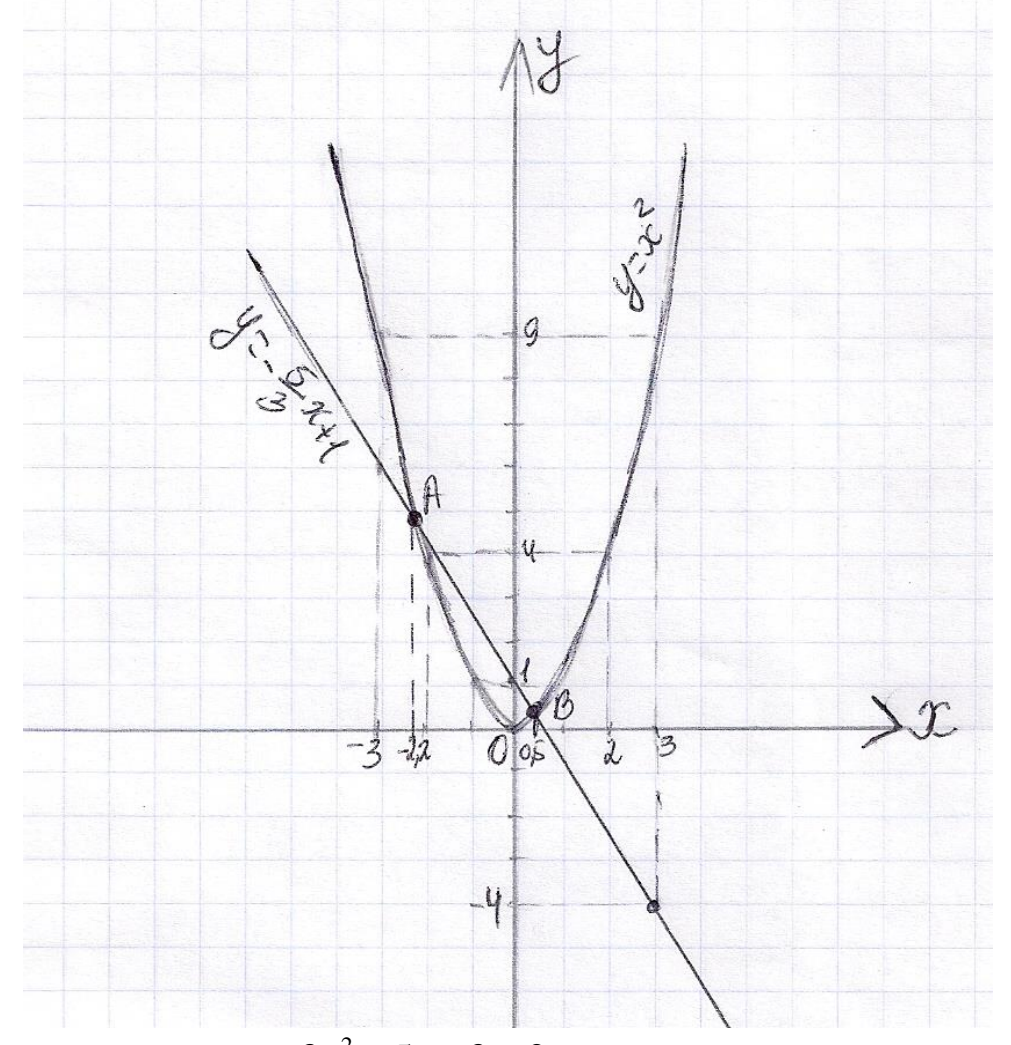

Şekil 9. $3 x^{2}+5 x-3=0$ denkleminin grafiği

Bu sorunun değerlendirilmesi "Karşılık gelen fonksiyonların grafiklerini aynı koordinat düzleminde çizerek kuadratik denklemin kökenlerini araştırıı” kazanımına göre gerçekleştirildi (Gehramanova, Kerimov ve Huseynov, 2019). (Tablo 4).

Tablo 4. Kontrol sinıfda $3 x^{2}+5 x-3=0$ denkleme göre değerlendirme

\begin{tabular}{|c|c|c|}
\hline $\begin{array}{c}\text { I seviye } \\
\text { yanlıș cevap }\end{array}$ & $\begin{array}{c}\text { II seviye } \\
\text { kismen doğru cevap }\end{array}$ & $\begin{array}{c}\text { III seviye } \\
\text { doğru cevap }\end{array}$ \\
\hline dereceden bir denklemin & İkinci dereceden bir denklemin & İkinci dereceden bir \\
\hline $\begin{array}{l}\text { köklerini bulmak için, aynı } \\
\text { koordinat düzleminde karşıllk } \\
\text { gelen fonksiyonlarının grafiklerini } \\
\text { oluşturmak zordur. }\end{array}$ & $\begin{array}{l}\text { köklerini bulmak için, karşılık } \\
\text { gelen fonksiyonlarının grafiklerini } \\
\text { aynı koordinat } \\
\text { oluşturur, ancak } \\
\text { yardımıyla inceler. }\end{array}$ & $\begin{array}{l}\text { köklerinin karşılık gelen } \\
\text { fonksiyonlarının grafiklerini aynı } \\
\text { koordinat düzleminde oluşturur ve } \\
\text { kökleri serbestçe inceler. }\end{array}$ \\
\hline
\end{tabular}

- Bir öğrenci aynı koordinat düzleminde bir parabolle düz bir çizgi grafiği oluşturamazsa, yanıtı yanlış kabul edilir.

- Öğrenci aynı koordinat düzleminde parabol ile düz bir çizgi grafiği oluşturur ancak ikinci dereceden denklemin kökenlerini öğretmenin yardımıyla bulursa, bu cevabın kısmen doğru olduğu düşünülür.

- Öğrenci aynı koordinat düzleminde bir parabol ile düz bir çizgi çizer ve ikinci dereceden denklemin köklerini serbestçe araştırırsa, bu cevap doğru cevap olarak kabul edilir.

Deney grubunda birinci soruya verilen cevapların analizi aşağıdaki gibi yapılmıştır: 
$y=\frac{8}{x}$ fonksiyonunnun tayin alanı 0-dan farklı tüm gerçek saylardır: $x \neq 0 . y=\frac{8}{x}$ fonksiyonunun Graph 4.4 yazılımında oluşturulmuş grafiği (Resim 10) aşağıdakı gibidir:

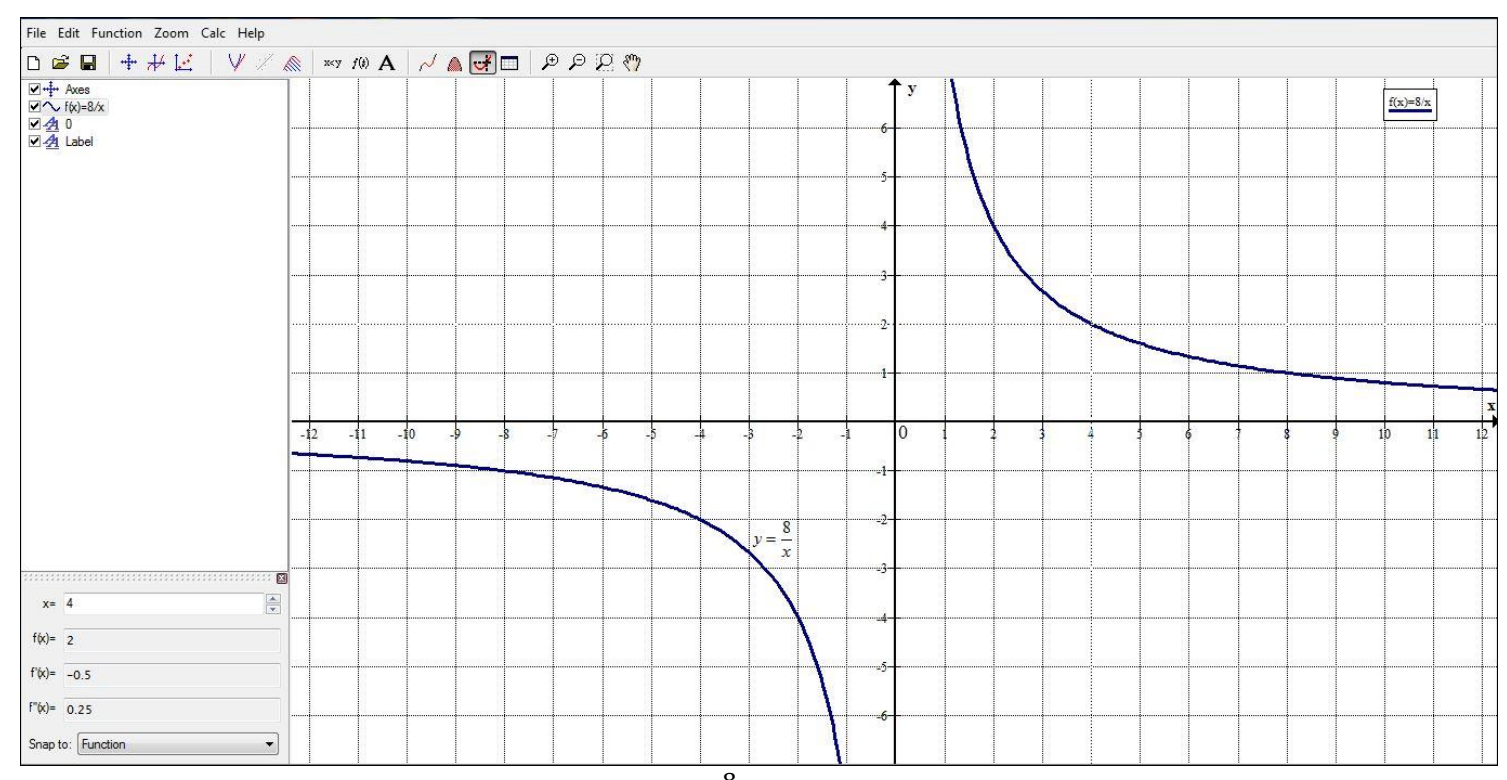

Şekil 10. $y=\frac{8}{x}$ fonksiyonunnun grafiğ i

İlk çalışma öğrencilerin deney sınıfindaki «Graph 4.4 kullanarak ters orantılılık grafiği sunma» becerisi üzerine derecelendirilmiştir (Tablo 5).

Tablo 5. Deney grubunda 1. Sorunun değerlendirme ölçütleri

\begin{tabular}{|c|c|c|}
\hline $\begin{array}{c}\text { I seviye } \\
\text { yanlış cevap }\end{array}$ & $\begin{array}{c}\text { II seviye } \\
\text { kısmen doğru cevap }\end{array}$ & $\begin{array}{c}\text { III seviye } \\
\text { doğru cevap }\end{array}$ \\
\hline $\begin{array}{l}\text { Graph } 4.4 \quad \text { kullanarak ters } \\
\text { orant1l1lık grafiği sunmak zordur. }\end{array}$ & $\begin{array}{l}\text { Graph } 4.4 \text { gösterimin yardımıyla } \\
\text { ters orantısallığın bir grafiğini } \\
\text { sunmaktadır. }\end{array}$ & $\begin{array}{l}\text { Graph } 4.4 \text { ters orantililik grafi } \\
\text { sunmaktadır. }\end{array}$ \\
\hline
\end{tabular}

Deney grubunda ikinci sorunun doğru ve eksiksiz cevabı aşağıdaki gibidir:

$3 x^{2}+5 x-3=0$ denkleminin onunla aynı güçlü olan $3 x^{2}=-5 x+3$ denklemi ile değiştirilmesi. Sonra denklemin her iki tarafinın 3-e bölünmeyle dönüştürülen ikinci dereceden denklemin kullanılması ve grafiksel çözmün yapılması: $x^{2}=-\frac{5}{3} x+1$. Ardından Graph 4.4 yazılımında $y=x^{2}$ ve $y=-\frac{5}{3} x+1$ fonksionlarının grafiklerinin oluşturulması. Grafiklerin kesişme nöktalarının absislerinin $-2,138$ ve 0,456 olarak belirlenmesi (Resim 11). Bu absisler $3 x^{2}+5 x-3=0$ denkleminin kökleridir. Denklemin çözümü $x_{1} \approx-2,138$ ve $x_{2} \approx 0,456$ olarak sonuçlanır. 


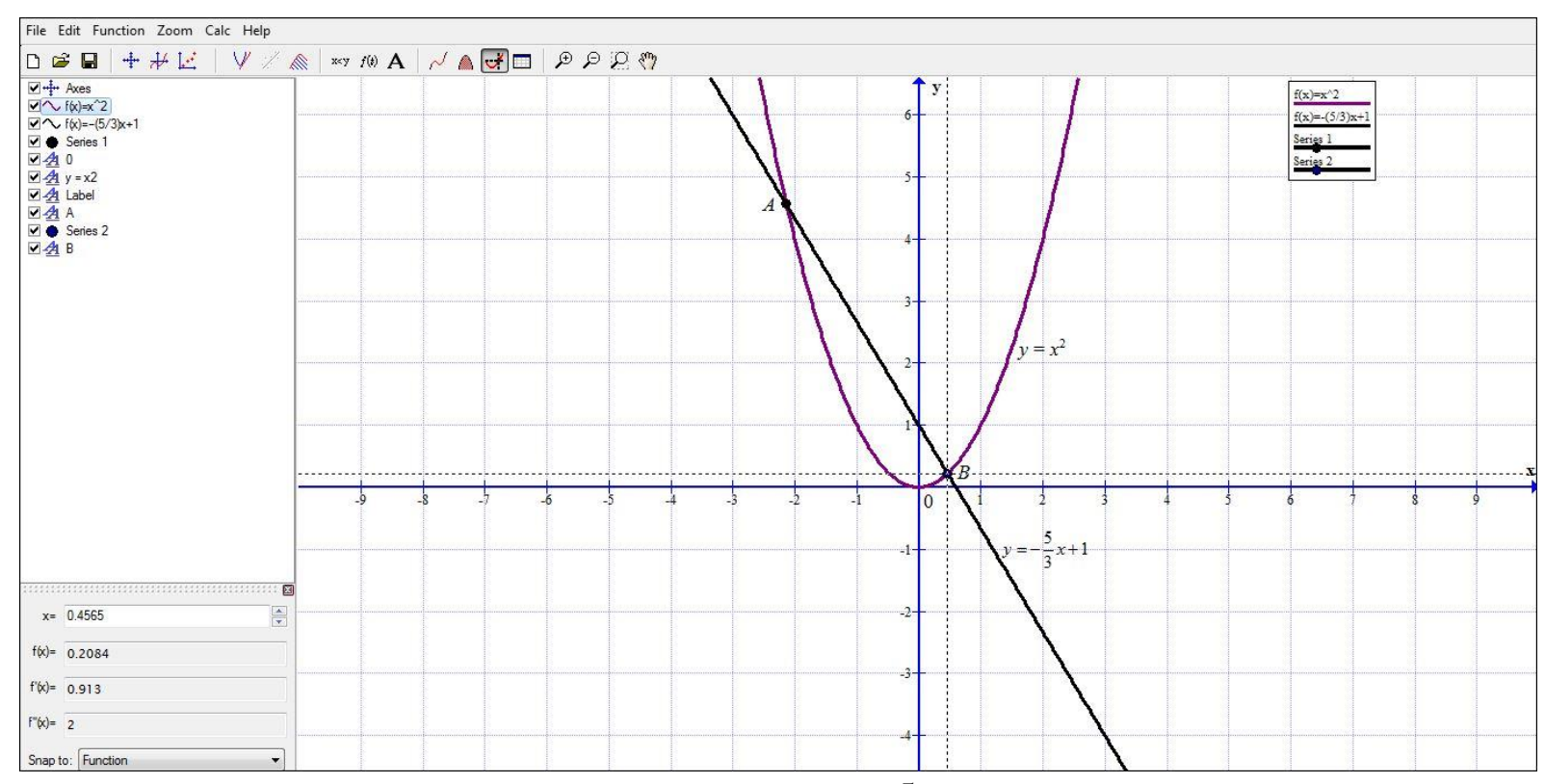

Şekil 11. Graph 4.4 yazılımında $y=x^{2}$ ve $y=-\frac{5}{3} x+1$ fonksionlarının grafikleri

Bu soru, "Uygun fonksiyonların grafiklerini oluşturma ve Graph 4.4 kullanarak sonuçları sunma" becerisi bağlamında Tablo 5'deki ölçütlere göre değerlendirilmiştir:

Tablo 5. Deney sınıfında $3 x^{2}+5 x-3=0$ denklemi için değerlendirme

\begin{tabular}{cccc}
$\begin{array}{c}\text { I seviye } \\
\text { yanlıs cevap }\end{array}$ & $\begin{array}{c}\text { II seviye } \\
\text { kısmen doğru cevap }\end{array}$ & $\begin{array}{c}\text { III seviye } \\
\text { doğru cevap }\end{array}$ \\
\hline uygun fonksiyonların & Graph 4.4 gösterimini kullanarak & Graph 4.4 gösterimini
\end{tabular}

Graph 4.4 uygun fonksiyonların Graph 4.4 gösterimini kullanarak Graph 4.4 gösterimini kullanarak grafiklerini çizmeyi uygun işlevlerin grafiklerini karşıllı gelen işlevlerin grafiklerini zorlaştırmaktadır. oluşturur, ancak sonucu yardımla oluşturur ve sonucu serbestçe sunar. sunar.

\section{Bulgular}

Graph 4.4 yazılımının öğrencilerin fonksiyon grafikleri oluşturma veyorumlama becerileri üzerindeki etkisi araştırıldı. Deney ve kontrol grubundaki cevapların frekans ve yüzdelik dağılımları Tablo 6'da verilmiştir:

Tablo 6: Deney ve kontrol grubundaki öğrencilerin cevaplarının dağılımı

\begin{tabular}{|c|c|c|c|c|c|c|c|c|c|c|c|c|c|c|}
\hline \multirow[b]{3}{*}{ Sorular } & \multicolumn{2}{|c|}{$\begin{array}{c}\text { Öğrencilerin } \\
\text { sayıs1 }\end{array}$} & \multicolumn{4}{|c|}{ Doğru Cevaplar } & \multicolumn{4}{|c|}{ Kısmen Doğru Cevaplar } & \multicolumn{4}{|c|}{ Yanlış Cevaplar } \\
\hline & \multirow{2}{*}{$\mathrm{D}$} & \multirow{2}{*}{$\mathrm{K}$} & \multicolumn{2}{|c|}{$\mathrm{D}$} & \multicolumn{2}{|c|}{ K } & \multicolumn{2}{|c|}{ D } & \multicolumn{2}{|c|}{ K } & \multicolumn{2}{|c|}{$\mathrm{D}$} & \multicolumn{2}{|c|}{ K } \\
\hline & & & $\mathrm{n}$ & $\%$ & $\mathrm{n}$ & $\%$ & $\mathrm{n}$ & $\%$ & $\mathrm{n}$ & $\%$ & $\mathrm{n}$ & $\%$ & $\mathrm{n}$ & $\%$ \\
\hline 1 & 24 & 22 & 8 & 33 & 4 & 18 & 14 & 58 & 10 & 45 & 2 & 8 & 7 & 32 \\
\hline 2 & 24 & 22 & 9 & 38 & 6 & 27 & 12 & 50 & 9 & 41 & 3 & 12 & 8 & 36 \\
\hline
\end{tabular}

Grafik hesaplamalar, grafik modelleme ve problemlerin grafiksel çözümü ortaokul sekizinci sınıf matematik müfredatının konuları arasındadır. Bu konunun deney sınıfında Graph 4.4 yazılımı kullanılarak öğretilmesi öğrencilerin fonksiyon grafiklerini çizime, grafiklere bağlı olarak hesaplama yapma ve fonksiyonun köklerini bulma yöntemlerinin öğrenilmesinde etkili olduğu Tablo 6'dan anlaşılmaktadır. Her iki gruba sorulan iki soruya öğrencilerin verdiği cevaplar incelendiğinde her iki gruptaki öğrenciler kağıt kalem etkinliği olarak fonksiyonların grafiklerini oluşturmada zorlandıkları belirlenmiştir. Öğrencilerin cevap kağıtlarından doğru ve kısmen doğru cevapların örnekleri aşağıda yer almaktadır:

Birinci soruyu doğru çözen öğrenciler fonksiyonun tanımlı olduğu alanı $\mathbb{R} \backslash\{0\}$ olarak belirlenmiştir (Resim $12)$ : 

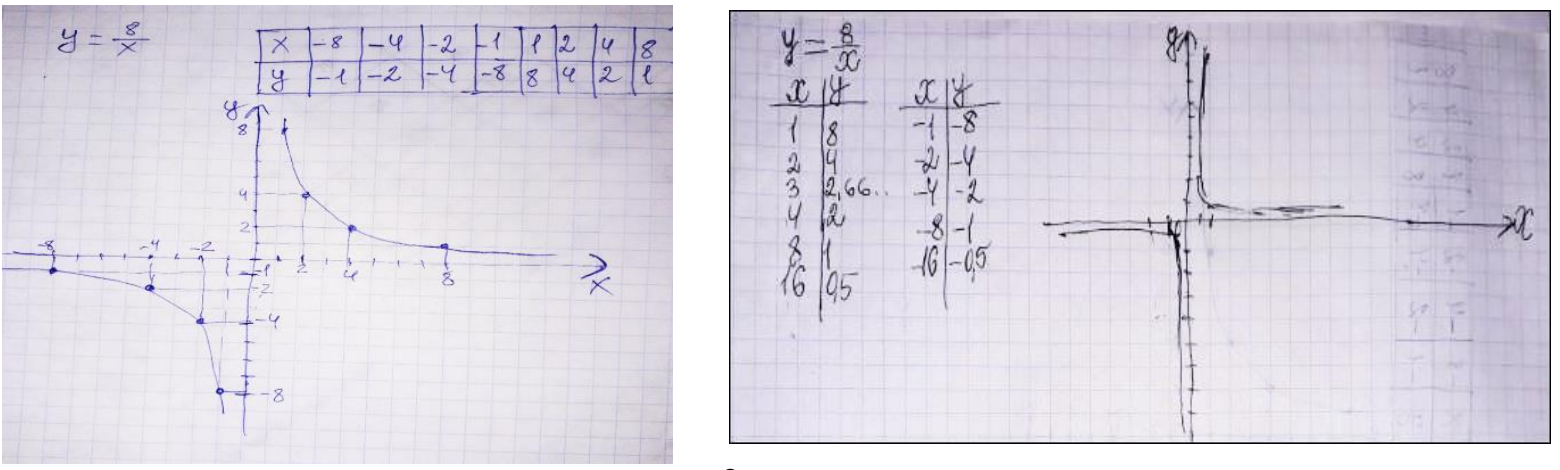

Şekil 12. $y=\frac{8}{x}$ için öğrenci cevapları

İkinci sorunun çözümünü öğrenciler farklı yollardan göstermeye çalışmıştır (Resim 13):
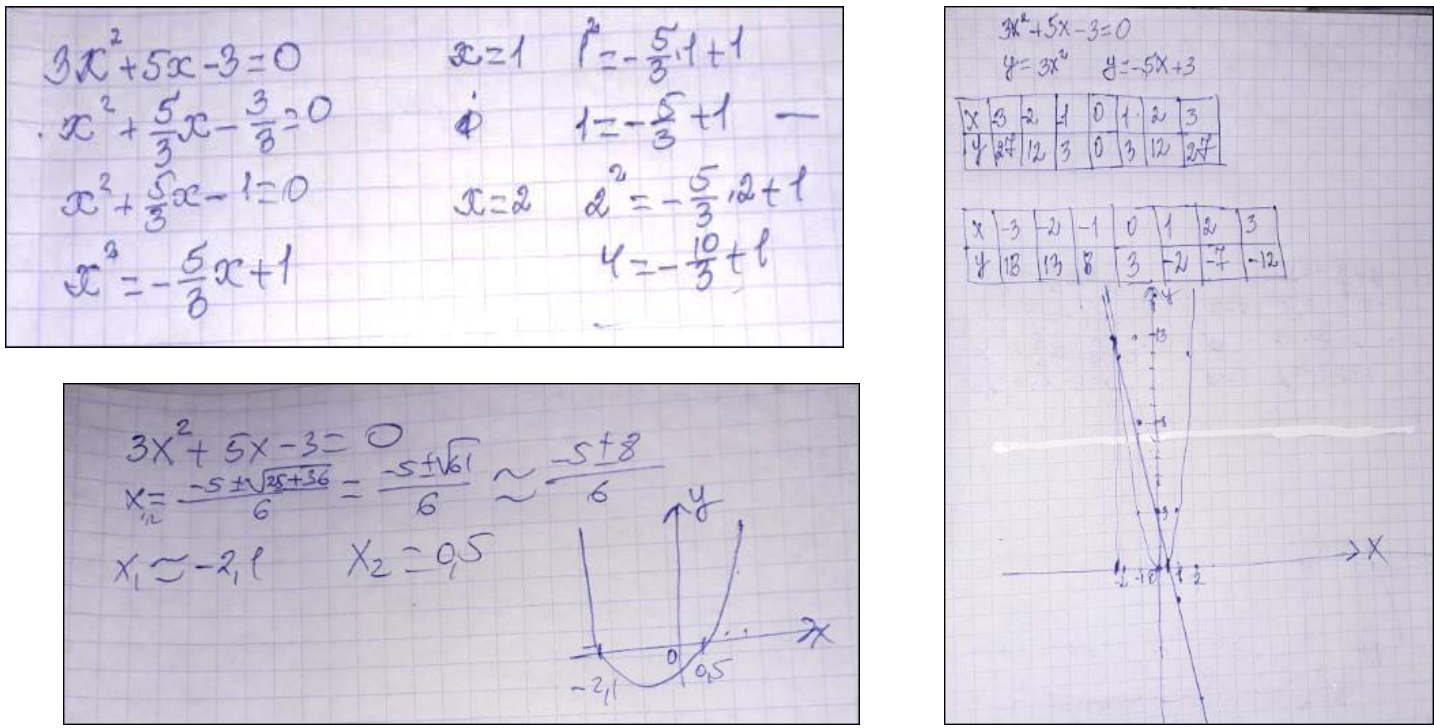

Şekil 13. $3 x^{2}+5 x-3=0$ denklemi için öğrenci cevapları.

Deney grubunun doğru ve kısmen doğru cevaplarının sayısı $(\mathrm{n}=42)$ deney grubundaki öğrencilerinkinden $(n=29)$ daha fazla olması ve yanlıs cevapların kontrol grubunda üç kat daha fazla olması Graph 4.4 uygulamalarının etkili olduğunu göstermektedir. Diğer bir deyişle, deney grubundaki öğrencilerin grafik çözüm yöntemlerine ilişkin problemleri çözme becerileri kontrol sınıflarına oranla $\% 13$ daha yüksek olduğu belirlenmiştir. Araştırmanın kapsamını genişletmekle, önerilen yazılımın öğrenciler için yüksek motivasyon kaynağı oluşturduğu ve matematik öğrenmede çok önemli bir yere sahip olduğu söylenebilir.

\section{Tartışma, Sonuç ve Öneriler}

Araştırmada ortaokul öğrencilerinin matematik derslerinde grafik becerilerinin geliştirilmesi imkânları ortaya konulmuştur. Bu deneysel çalışmada ayrıntılı hipotez testleri yapılmadı. İki grup sadece iki soruya verilen cevaplar üzerinden karşılaştıııldı, yüzdeliklerine bakıldı ve yazılımın etkisi ile ilgili yorumlar yapıldı. Elbette bu tür sınırlı bir çalışmanın bulguları genellenemez. Bu sonuçların genellenebilmesi için daha büyük bir örneklemin ve daha fazla sorunun olduğu araştırmanın kullanılmasına ihtiyaç vardır. Dolayısıyla bu çalışma sadece Bakü'de bir ortaokulda yapılan uygulamadan kesitler sunmaktadır. Çalışmanın sınırlı sonuçlarına bağlı olarak, öğrencilerin fonksiyon grafikleri ve çözümleri ile ilgili öğrenmelerini desteklemek amaciyla ortaokul matematik derslerinde Graph yazılımının kullanımı önerilebilir.

Fonksiyon grafikleri oluşturma ve yorumlama becerisi ortaokulların matematik müfredatındaki önemli becerilerden biridir (Azerbaycan Milli Eğitim Bakanlığı, 2013). 8. sınıf matematik müfredatında cebir ve fonksiyonlar içerik çizgisine uygulanacak standartlar öğrencilerin düşünme becerilerini geliştirir, gerçek yaşamdaki durumları anlamaya hazırlar. Standartların (Qehramanova, Kerimov ve Huseynov, 2019) uygulanması aşağıdaki beceriler üzerinde gerçekleştirilir:

$\checkmark a x^{2}+b x=0, a x^{2}+c=0, a x^{2}+b x+c=0$ tip denklemlerin çözümü $y=a x^{2}$ ve $y=$ $k x+d$ fonksiyon grafiklerinin kesişme noktasının apsisi olarak anlar; 
$\checkmark$ Karşılık gelen fonksiyonların grafiklerini aynı koordinat düzleminde çizerek kuadratik denklemin köklerini araştırır;

$\checkmark \quad$-Elektronik grafik hesaplayıcıları kullanarak uygun fonksiyonların bir grafiğini oluşturur ve sonuçları sunar.

Çalışma sırasında öğrencilerin bu becerilere tam olarak hakim olmadığı görülmüştür. Bunun birkaç nedeni ilgili literatürde ifade edilmektedir:

$\checkmark \quad$ İlkokuldan beri bazı öğrencilere matematiğe ilgi eksikliği;

$\checkmark \quad$ Matematiksel konuların sınıftan sınıfa basitten karmaşıklığa geçişi;

$\checkmark$ Öğrenciler yaşlandıkça, ilgi alanları genişler ve sonuç olarak matematiksel bilgi ve becerilerini geliştirmek için daha az zaman harcanması;

Öğretmenler tarafından yeni teknolojilerin zayıf kullanımı, özellikle bilgisayar teknolojisinin zayıf kullanımı (Mehrabov ve Cavadov, 2007).

$\mathrm{Bu}$ araştırmadan, öğrencilerin fonksiyonların grafiklerini oluşturma ve yorumlama becerilerini geliştirmede öğretmen tarafından seçilen bilgisayar detekli yöntemin önemli bir rol oynadığı anlaşılmaktadır. Hafiza okulundan düşünme okuluna geçiş, her öğretmenin «yetkinliğe dayalı kişilik odaklı eğitim içeriği yaratmasını» gerektirir (Abbasov, 2019). Yani, bugün öğrenci tarafından edinilen bilgi, geleneksel eğitimde olduğu gibi öğrenme materyallerinin açıklayıcı bir tanımını gerektirmez. Burada öğrencinin kişiliğinde oluşacak yeterlilikler ifade edilir. $\mathrm{Bu}$ beceriler temel olarak öğretme-öğrenme sürecinin bir sonucu olarak oluşur. Eğitim sürecinin gerçekleştirdiği işlevlerden biri gelişmektir (Adigozalov, 2012). Gelişimin sağlanması için eğitimin yönlendirilmesi gerekmektedir. Matematik öğretmenleri de dâhil olmak üzere her öğretmen, öğrencilerin becerilerinin gelişimi için elverişli koşullar yaratmak için öğrenme sürecinin firsatlarını kullanmalıdır. İlköğretimden itibaren öğrencilerin düşünme becerilerinin oluşturulması, eğitimin ilerleyen aşamalarında daha karmaşık bilişsel becerilerin (problem çözme, yargılama, ispat, koordinasyon, sunum) geliştirilmesine yol açacaktır. (Azerbaycan Milli Eğitim Bakanlığı, 2013; Abbasov, 2019).

Teknoloji hızla ilerliyor. Bu gelişme aynı zamanda bilim ve eğitim yönünü de değiştirmektedir. Gerçekleşen değişikliklere ayak uydurmak için toplumun insanlardan beklediği yetenekler de değişmeli ve gelişmelidir. Bu açıdan matematik eğitiminin bilim ve teknolojideki gelişmelere uygun yapılmasını sağlamak gerekir. Matematik bilgisinin öğrenilmesi ve uygulaması için BİT'in kullanımı günümüz matematik derslerinin temel gereksinimlerinden biri olmalıdır. Matematik derslerinde Graph 4.4 yazılımın kullanılması, öğrencilerin çalıştıkları konularda bilgi, beceri ve alışkanlıklarını oluşturmalarına ve geliştirmelerine, bunları gerçek yaşam durumlarına uyarlayabilmelerine ve öğrencilerin ödevlerinden sorumlu olmalarına yardımcı olacaktır.

\section{Kaynaklar / References}

Azerbaycan Milli Eğitim Bakanlığı (Azerbaijan Ministry of National Education) (2013). Cumhuriyeti okullar için matematik dersinden ĕgitim programı (ders müfredatı) (I-XI. Sınıflar). https://edu.gov.az/ adresinden 19 Nisan 2020 tarihinde edinilmiştir.

Azerbaycan Milli Eğitim Bakanlığı (Azerbaijan Ministry of National Education) (2006). Milli kurrikulum [Ulusal müfredat]. https://edu.gov.az/upload/file/milli_kurikulum-eng.pdf adresinden 19 Nisan 2020 tarihinde edinilmiştir.

Ahmedov, A., ve Abbasov E. (2008). Illkokulların 1.-4. sınıfları üçün ders müfredatları. Bakü: Eğitim.

Abbasov, M. (2019). Müfredat kılavuzu (açıklamalar ve uygulamalar) Bakü: Elm ve tehsil.

Adigozalov A. S. (2012). Ortaokulda matematik ögretim metodolojisi (genel metodoloji). Bakü: ADPU.

Azerbaycan Başkanlık Kararnamesi, (2013). Azerbaycan Cumhuriyeti'nde ĕgitimin gelişmesi için devlet stratejisi. http://www.president.az/articles/9779 adresinden 12 Mart 2018 tarihinde edinilmiştir.

Azerbaycan Başkanlık Kararnamesi, (2016). Azerbaycan Cumhuriyeti'nin ulusal ekonomik beklentileri için stratejik yol haritasi. https://static.president.az/pdf/38542.pdf adresinden 20 May1s 2020 tarihinde edinilmiştir.

Abdullayeva, M. (2012). Matematik derslerinde bilgisayarda uygulama yazılımlarının kullanım kilavuzu. Fizik, Matematik ve Enformasyon Ĕ̈itimi Dergisi, 1(195), 38-43.

İsmayılova, S. (2014). Matematik - Ortaokulların 7. sınfı için ders kitabı. Bakü: Doğu-Batı.

Johansen, I. (2012). Graph 4.4.2. Retrieved from http://www.padowan.dk on May 20, 2020.

Qehramanova, N., Kerimov, M. ve Hüseynov, İ. (2015). Matematik-Ortaokulların 8. Sinfi için ders kitabı. Bakü: Radius.

Qehramanova, N., Kerimov, M. ve Hüseynov, İ. (2019). Matematik-Ortaokulların 8. sınıf için matematik konu ögretmeni için metodik el kitabı. Bakü: Radius.

Merdanov, M. C. (2010). Matematik. Liselerin 9. sınfi için ders kitabı. Bakü: Çaşığlu.

Merdanov, M. C. (2009). Cebr ve analizin başlanğıcı. Liselerin 11. sınfı için ders kitabı. Bakü: Çaşığlu.

Mehrabov, A. O. ve Cavadov, İ. A. (2007). Ortaokullarda izleme ve değerlendirme. Bakü: Mütercim. 
Peter, E. E. (2012). Critical thinking: Essence for teaching mathematics and mathematics problem solving skills. African Journal of Mathematics and Computer Science Research, 5(3), 39-43.

Tagiyeva, Z., Hesenov, G. ve Cebrayılzade, S. (2011). Enformatik ve BİT. Bakü: Çaşığlu. 